\title{
منهج الإمام الشـافعي في كتابه ( الأم )
}

\author{
نجاح شاهرسعد الغضباني \\ محاضر بقسم الدراسات الاسلامية - كلية التربية بمحافظة الدوادمي -جامعة شقراء- المملكة العربية السعودية \\ najah@su.edu.sa
}

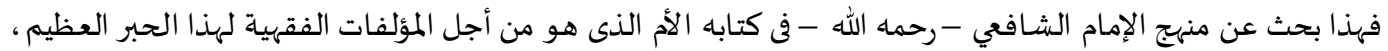

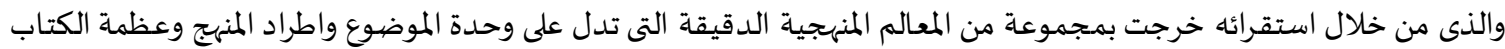

وقد جاء البحث فى مقدمة ومبحثين وخاتمة بها أهم نتائج البحث وتوصياته ، ثم ثبت بأهم مراجع البحث ثم فهرساه . وفي المقدمة تناولت بإيجاز تعريفاً بالكتاب وأهميته وأسباب اختياره للبحث، ثم منهج البحث وخطتها، كما بينت مشكلة الدراسة، كما هو العادة في مثل هذه البحوث البـان. أما المبحث الأول فكان عنوانه: " الإمام الشـافعي وكتابه الأم " تناولت فيه قبساً من سيرة الشـافعي، ثم تحدثت عن كتاب

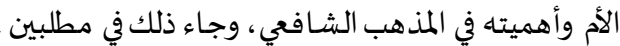
أما المبحث الثاني فكان عنوانه: " المعالم العامة لمنهج الإمام الشافعي في كتابه الأم "، تناولت فيه ثمانية عشر معلمًاً، واستشهدت لكل معلم من نصوص الإمام للتدليل عليه . وأخيراً جاءت خاتمة البحث وفيها أهم نتائجاه وتوصياته ، ثم ثبت بأهم مراجع البحث، ثم فهرسه.

الكلمات المفتاحية: الإمام الشـافعي؛ المذهب الشافعي؛ كتاب الأم

\section{(c) (1)}

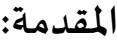

$$
\text { بسم الله الرحمن الرحيم }
$$

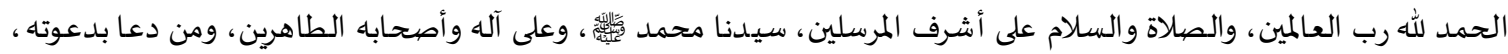
وسار على هديه إلى يوم الدين.

سبحانك ربى! آثرت عقول عبادك الصالحين بالعلم، ونفوسهم بالحلم؛ ففازوا بجنة الدنيا قبل جنة الآخرة، وبعد، ، فإن علم الفقاه في الدين جليل القدر ، خطير الأثر؛ وذلك لما يترتب عليه من صحة العبادة أو المعاملة أو بطلانهما، وبريما

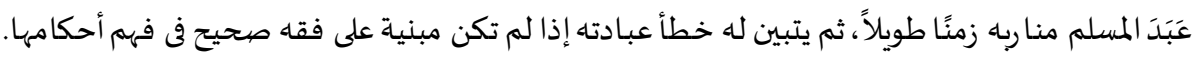

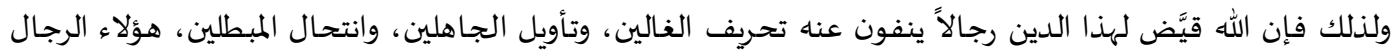
يعملون بالليل والنهار من أجل رفعة هذا الدين، وحمايته، وعلو شأنه، ثم يقدمون أحكامه للناس بيضياء نقياة، لا غموض فيها ولا لان

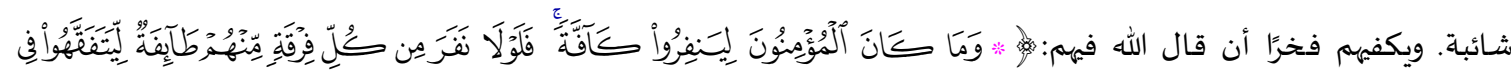

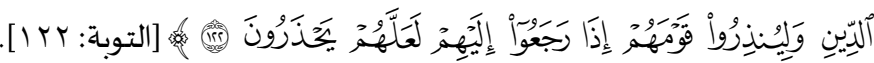

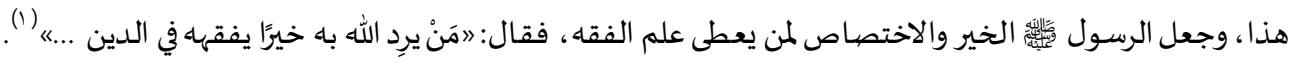


ومن هؤلاء الأعلام الإمام "محمد بن إدرد الشافعي" (r). مفخرة علماء الإسلام عامة، ومفخرة علماء الشافعية على وجها

الخصوص. والذى خدم الإسلام خدمات جليلة بتأليفه في جميع فروعاء.

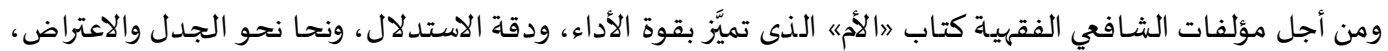

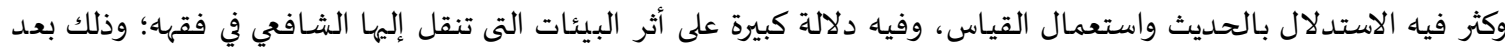
ستقراره في مصر .

\section{مشكلة الدراسـة :}

على الرغم من كثرة الدراسات والبحوث التى تناولت الإمام الشـافعي وكتابه " الأم " إلا أن الباحثة لم تقف على دراسة

أصلت لمنهج الإمام في هذا السفر الجليل الذي يعتبر نواة الكتب التى نهل منها الشـافعية من بعد الإمام، رحمه الله تعالى . وحاولت هذه الدراسـة الإجابة عن السؤال التالي: هل سار الإمام الشافعي في كتابه " الأم " على منهج مطرد أم أن الكتاب مجرد

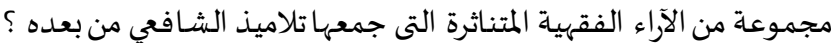

وفي سبيل الإجابة عن هذا السؤال المهم قامت الباحثة باستقراء الكتاب، ومن خلال هذا الاستقراء التام خرجت بمجموعة مهنة من أهم المعالم المنهجية الدقيقة التي تدل على وحدة الموضوع واطراد المنهج وعظمة هذا المؤَلَّف وصياحبه.

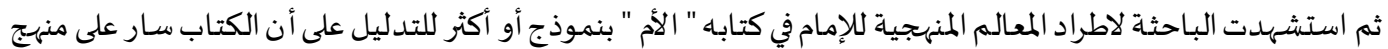

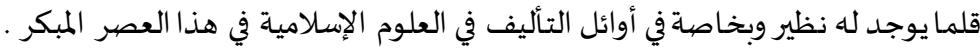

أهميـة الدراسـة : مأد

تنبع أهمية الدراسة من أهمية موضوعها، فقد توجهت الدراسة لأهم معالم الإمام الشافعي المنهجية للأسباب التالية:

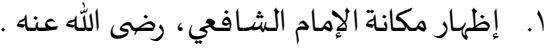

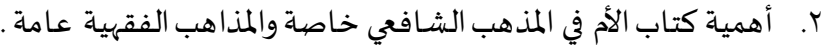
ع. أطراد منهج الإمام في كتابه كله ع. احتواء الكتاب على كثير من القواعد الفقهية والأصولية، كما أنه اشتمل على المناظرات العلمية الدقيقة 0. إضافة بحث جديد للمكتبة الإسلامية يثري الدراسات الشرعية ويفيد الباحثين في هذا المجال .

أهداف الدراسـة : اف

تهدف هذه الدراسة إلى بيان ما يلي :

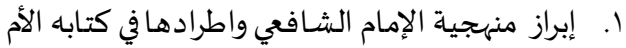

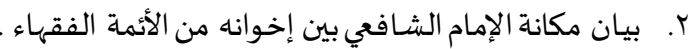

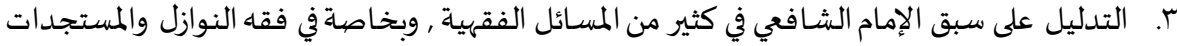

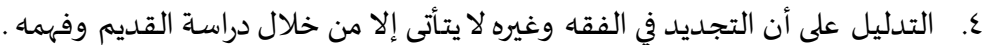

اعتمدت هذه الدراسة المنهج الوصفى الاستقرائي؛ وذلك بوصف أهم خطوات حياة الإمام، ثم استتقراء أهم المعالم التي

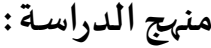

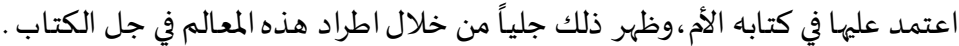

خطة الدراسـة :

جاءت هذه الدراسة في مقدمة ومبحثين وخاتمة وثبت بأهم المراجع. أما المقدمة: ففهيا تعريف موجز بالكتاب وصاحباه وخطة بحثاه ومنهجهاه.

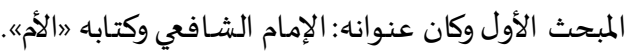

ستأتي ترجمة تفصيلية للإمام محمد بن إدريس الشافعي موضوع هذا البحث في المبحث الأول , إن شاء الله تعالى. المجلة الدولية للدراسات الإسلامية المتخصصية _ـ المجلدب، العدد ا - 19 ب r 


$$
\begin{aligned}
& \text { وفيه مطلبان: } \\
& \text { المطلب الأول: قبس من سيرة: الإمام الشـافعي. }
\end{aligned}
$$

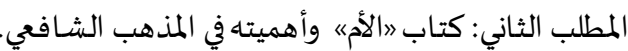

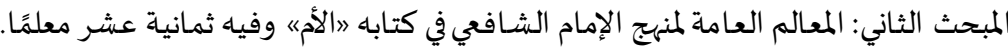

$$
\begin{aligned}
& \text { ثم الخاتماة ، وبها أهم نتائج البحث وتوصياته. } \\
& \text { ثم ثبت بأهم مراجع البحث. }
\end{aligned}
$$

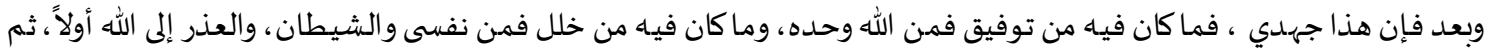

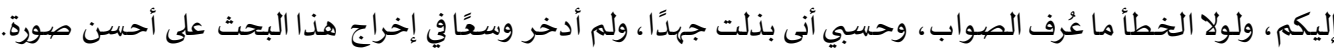
والله ولي التوفيق.

$$
\begin{aligned}
& \text { المبحث الأول: الإمام الشـافعي وكتابه الأم } \\
& \text { وفيه مطلبان: } \\
& \text { الأول: قبس من سيرة الإمام الشـافي. معبي. } \\
& \text { الثاني: كتاب الأم وأهميته في المذهب المناف الشـافي. } \\
& \text { المطلب الأول: قبس من سيرة الإمام الشافعي وفيه: }
\end{aligned}
$$

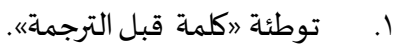

$$
\begin{aligned}
& \text { r. الإمام الشـافي: مولده ونسبه. }
\end{aligned}
$$

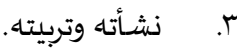

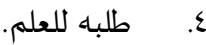

$$
\begin{aligned}
& \text { 0. صفاته وأخلاقه. }
\end{aligned}
$$

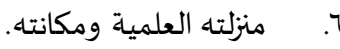

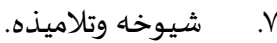

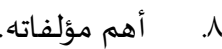

$$
\begin{aligned}
& \text { 9. ثناء العلماء عليهاء. } \\
& \text { • ا. . وفاته. }
\end{aligned}
$$

المطلب الأول: قبس من سيرة الإمام الشـافعي

1. توطئة: كلمة قبل الترجمة:

ما من شلكٍ في أنه على قدر أقدار الرجال تأتى تراجمههم وبقدر تأثيرهم يبقى ذكرهم، فسيرتهم العطرة تفوح رائحته رغم تقادم الزمان وتباعد المكان، ويعظم الأمر إذا كنا أمام إحدى الشخصيات الإسلامية التي أثرت الفكر الإسلامي خاصهة، والفكر

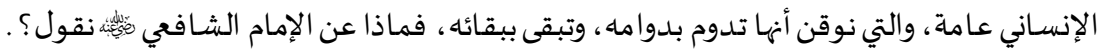
ربما تكون الترجمة لشخصية ما من ذكر أحوال العصر الذى عاشت فيه، سياسية كانت أو اجتماعية أو علمية أو

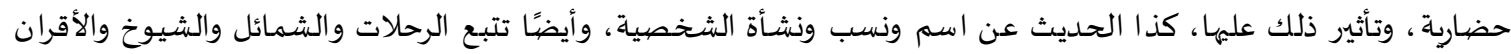
والتلاميذ، ثم الوفاة... ريما يكون هذا كله أقرب إلى الدراسات التارنخية والوصفية منها إلى الدراسـات الفقهية.

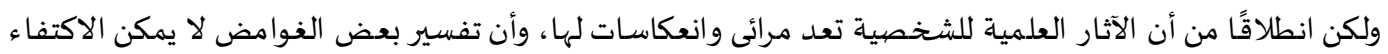
فياء بالأثر العلمي وحده، وأن الظالال والخلفيات لها دور مملوس في توجياء كثير من الأمور؛ بل إننا نجد كثيرًا من التراث الإسلامي -

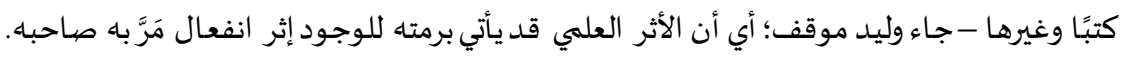

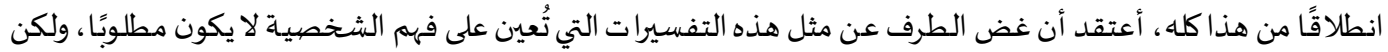

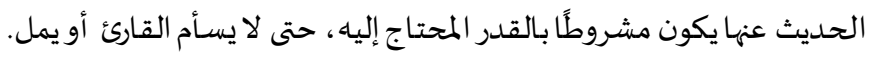




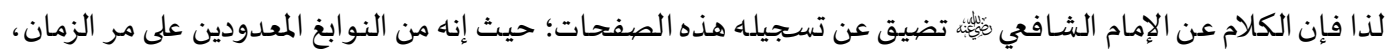
كما أن جوانب الحديث عنه تتعدَّد بتعدُّد مواهبها، فالكلام عن جوانبه العلمية من شمول علم، وسعة حفظ، وقوة انتباه، ودقة

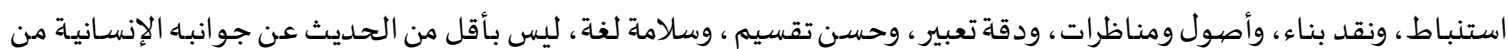
عفو وحلم، وإيمان وتقوى، وزهد وورع، وجود وكرم، وصبر ورضا، إلى غيرها من الشمائل والمحاسن التي ذكرتها الكتب التي ترجمت وقد سوَّد العلماء الأجلَّاء في تفصيل إجمال هذه الصفات - صفحات؛ بل كتبًا ومجلدات، ومنهم من أفرد للحديث عن عناه. سيرته مؤلفًا خاصَّا، الأمر الذى يجعل فياء الغناء.

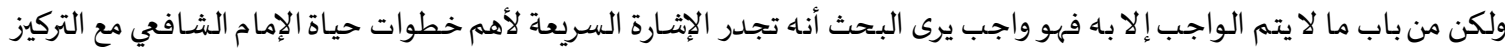

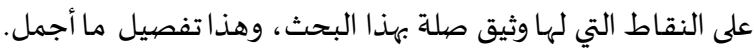

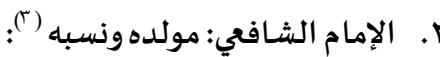

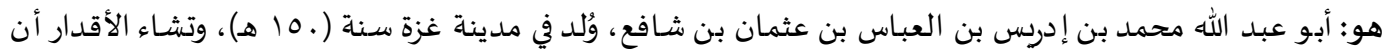

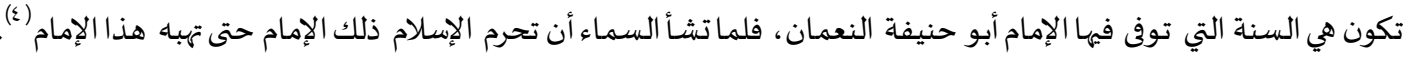

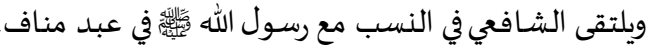

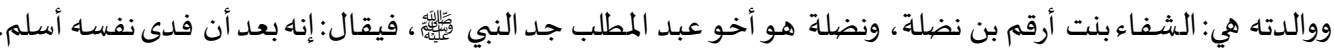

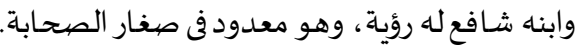

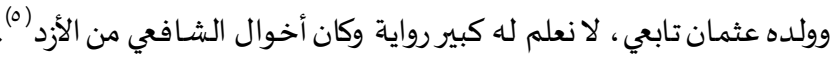

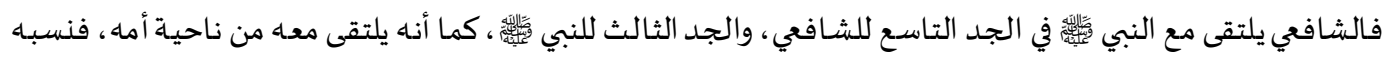

$$
\text { لآل البيت ثابت من كلا الأبوين، وكفى بهذا شرفًا ورفعةً. }
$$

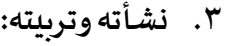

نشأ الإمام الشافعي يتيمًا في حجر أمه، فـانتقلت باه من غزة إلى مكة وهو ابن سنتين؛ حتى ينشأ على ما ينشأ عليه أقرانه من

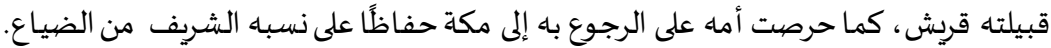

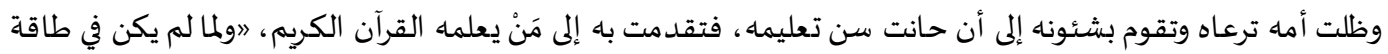

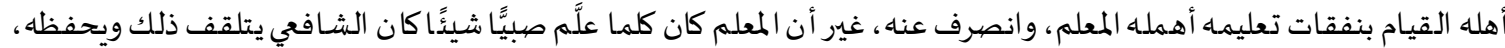

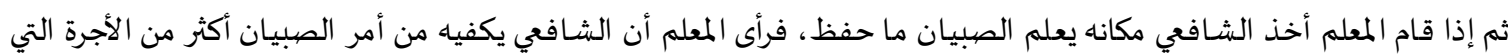

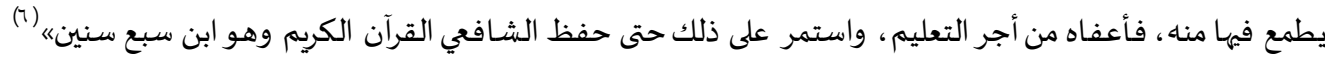

$$
\begin{aligned}
& \text { "كلإمام الشافعي ترجمة في كثير من المراجع، منها: } \\
& \text { - } \\
& \text { - - - مناقب الشافعي لأبى بكر أحمد بن الحسين البيهي. }
\end{aligned}
$$

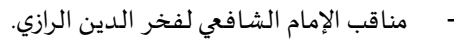

$$
\begin{aligned}
& \text { - - مناقب الإمام الشافعي لابن كثير. }
\end{aligned}
$$

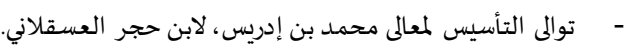

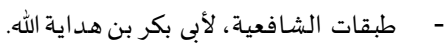

$$
\begin{aligned}
& \text { - - - - مبقات الشافعية الكبرى، لابن السبكي (تاج الدين). }
\end{aligned}
$$

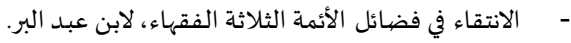

$$
\begin{aligned}
& \text { - - - ل الشافعي حياته وعصره وآراؤه الفقهيية، لألبى زهرة. }
\end{aligned}
$$

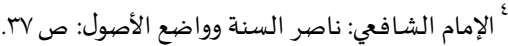

$$
\begin{aligned}
& \text { " تاريخ علم أصول الفقه: ص } 90 .
\end{aligned}
$$

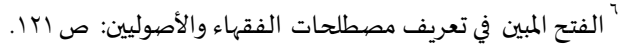

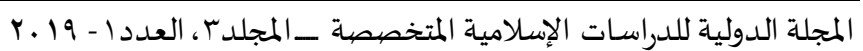


والخلاصة أن الحدث الناشئ أدرك جلالة المكان ومهابة الدروس، ومكانة الأساتذة الذين يتحلق حولهم، وربط الماضي

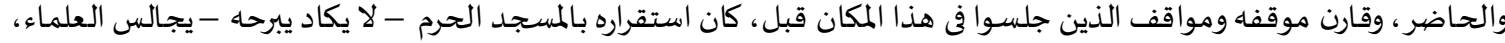

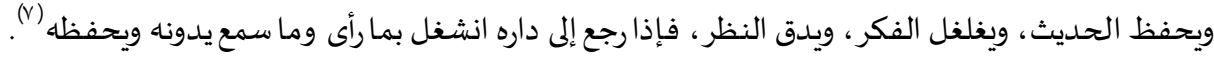

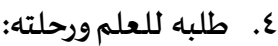

بالطبع لم يكن يتوافر لهذا الحبر الجليل هذا القدر من العلم والفضل، والمعرفة والحلم، إلا ببحث دؤوب، وطلب للمعرفة في شتى بقاع الأرض. فقد خرج إلى قبيلة هذيل (1) بالبادية لشهرتها بالفصاحة والبيان ، وأقام هها مدة، حفظ فيها اللغة وأشعار العرب، وأخبارهم

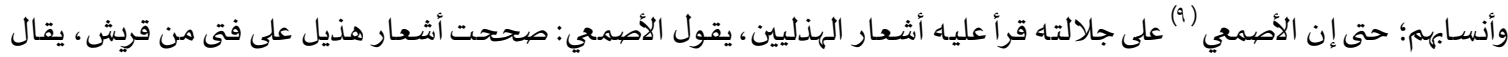

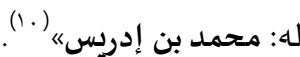
اشتغل الشافعي- كما ذكرت كتب السير عنه- بالعربية عشرين سنة مع بلاغته وفصاحته؛ حتى شهد له أئمة اللغة

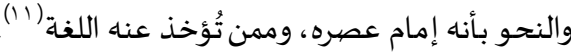

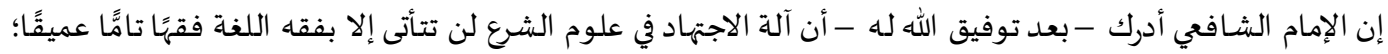

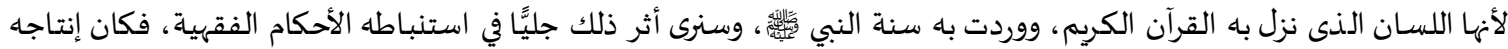
متميزًا في الفقه الإسلامي وأصولها عاد الشافي من البادية إلى مكة فلزم مسلم بن خالد الزنجي (r) مفتى مكاة وتفقهاه باه حتى أذن له في الإفتاء وهو ابن خمس

كان الإمام مالك - وقتها - قد طبقت شهرته الآفاق، وتناقل الناس كتابه هالموطأه، وسمت همة الشافعي إلى الذهاب إليه

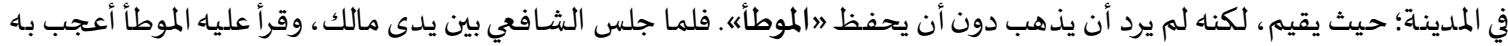

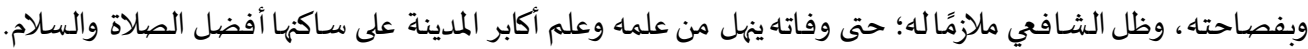

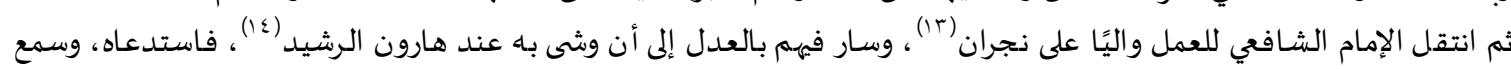
فرد عن نفساء بالبيان والفصاحة، فأطلق سراحها.

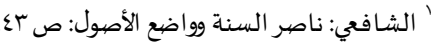

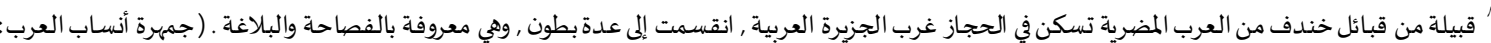
(197 صن (197)

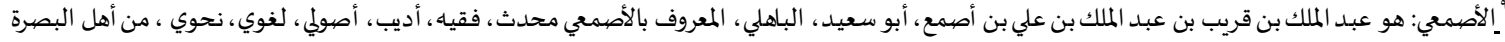

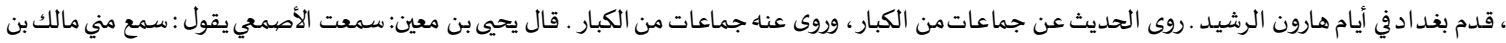

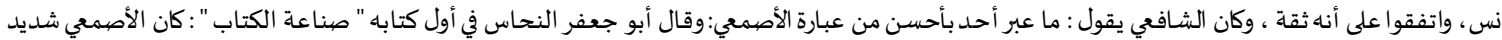

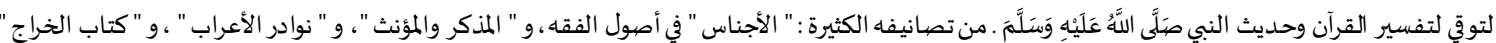

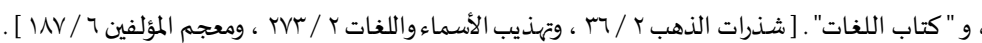
'تاريخ علم أصول الفقه: ص 90.

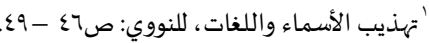

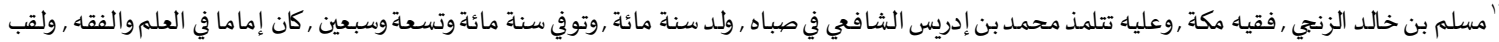

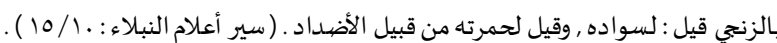

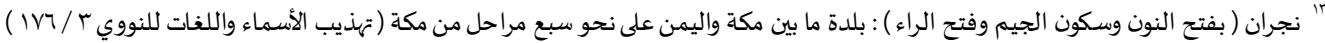

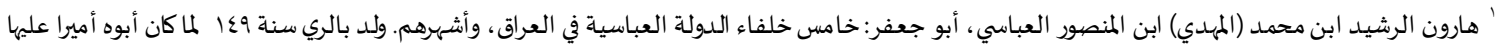
وعلى خراسان .ونشأ في دار الخلافة ببغداد إنداد.

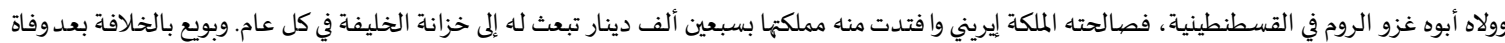

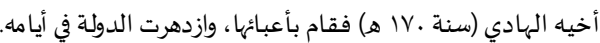

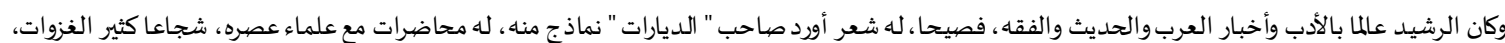

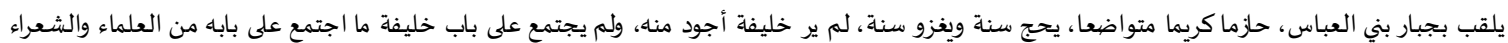

والكتاب والندماء. وكان يطوف أكثر الليالي متنكرا.

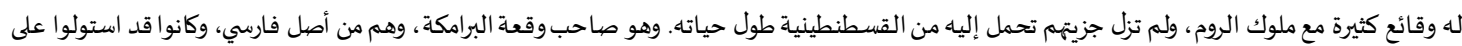

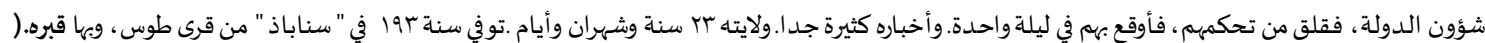

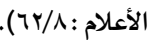


ظل الإمام الشافعي في بغداد (10) ، واتصل بإمام الحنفية هناك محمد بن الحسن (17)، فلازماه وقرأ كتبه عليه ، وبذلك اجتمع

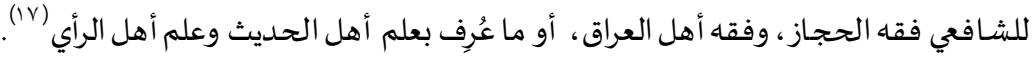

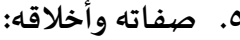

ذكر العلماء أن الإمام الشـافعي حين قدم مصر استقبله تلميذه الربيع المرادي (1)، ونصحهه بأن يجعل لنفسه مكانة عند الحاكم؛ ليكون عزيزًا في نظر الناس، وأن يدخر فى بيته طعام سنة فرد عليه الشافعي قائلاً: يا ربيع ، من لم تُعزّه التقوى فلا عزَّ له ،

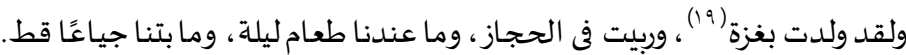

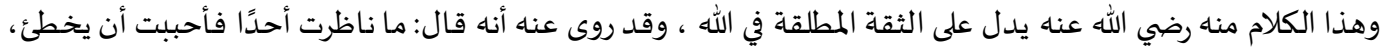
وما في قلبي من علمٍ إلا وودت أنها عند كل أحد ولا ينسب إلَّى (.r). أما عن زهده وورعه، فقده روى عنـه أنها قال: أفلست ثلاث مرات، فكنت أبيع قليلي وكثيري؛ حتى حلى ابنتي وزوجتي ، ولم استدن (r) ق كان الشافعي جوادًا كريمًا قدوة في ذلك، لما عفا عنه الرشيد، ومنحه خمسين ألف دينار ، ففرقها على حجاب أمير المؤمنين قبل أن يخرج من القصر (rr)

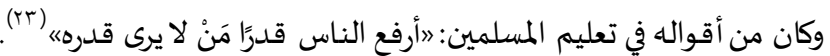

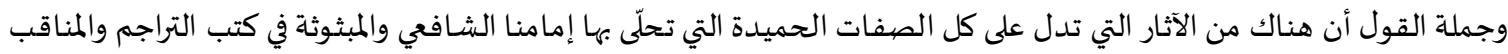
التي ألفت - ولا تزال - في هذا الإمام الجهبذ، وما ذكرناه على سبيل المثال لا الحصري ، ومن أراد الاستزادة فليراجع ذلك في موضعاتيه.

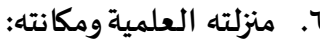
يُعد الإمام الشافعي تِلئن: ظاهرة فريدة في الفقه الإسلامي، تميّز بخصائص منهجية وفكرية، قلما توافرت في فقه فقيه من فقهاء الإسلام.

"بغداد : بناها الخليفة المنصور ودعاها مدينة السلام وبدأ في بنائها سنة هـ ا هـوانتهى بناؤها سنة وعا هـ ـظلت عاصمة بني العباس حتى آخر خلفائهم وكانت

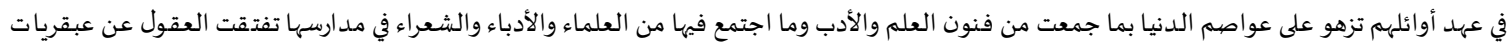

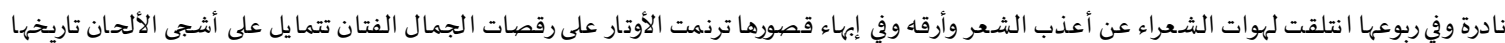

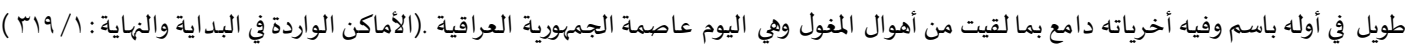

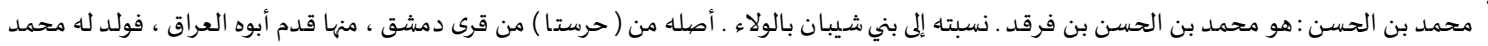

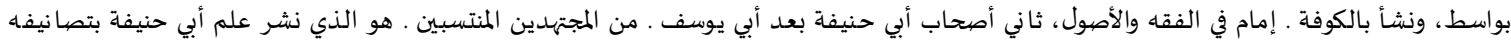

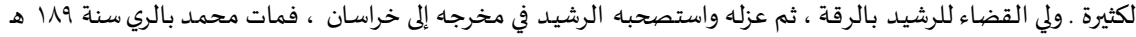

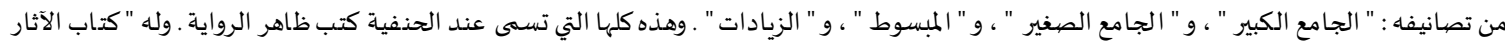

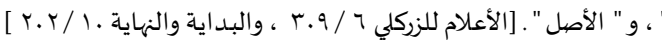

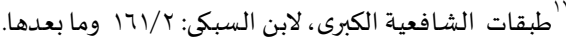

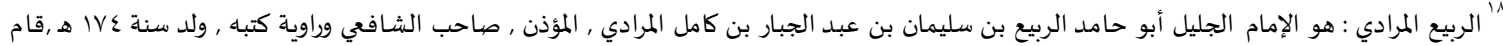

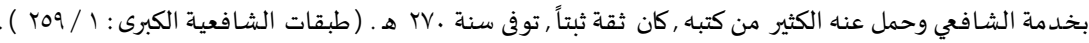

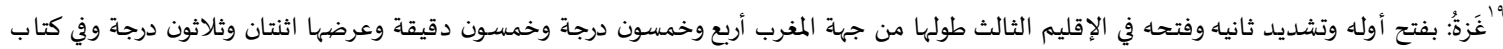

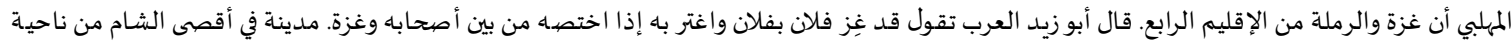

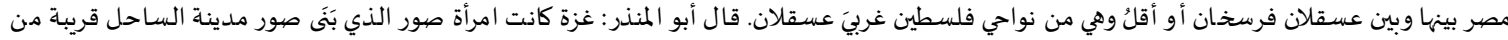

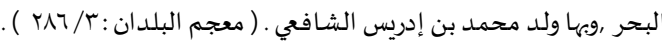

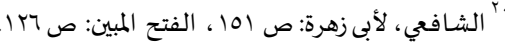

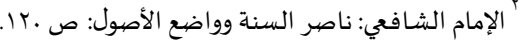

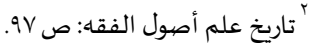

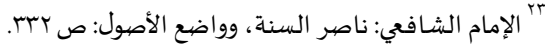


يقول الإمام الماوردي (عَ) في مقدمة كتابه 》الحاوي《: "لما كان محمد بن إدردس الشـافعي قد توسَّط بحجتي النصوص

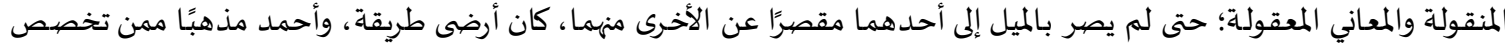

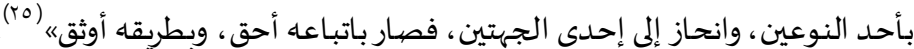

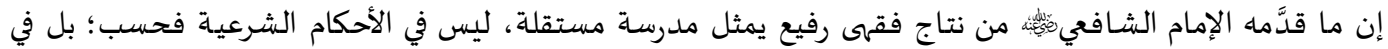

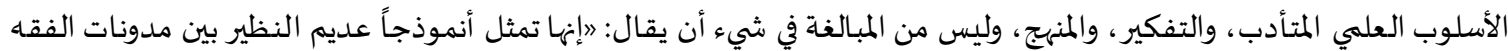

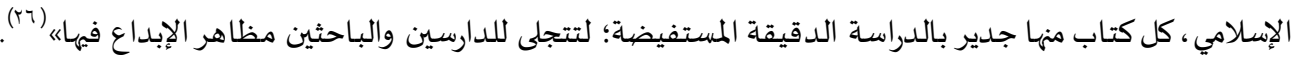

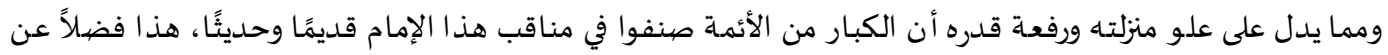

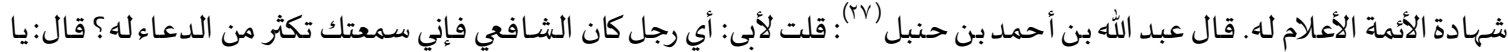

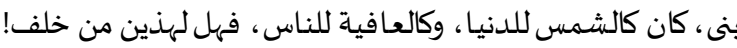
وقال:كان الشافعي من أفصح الناس.

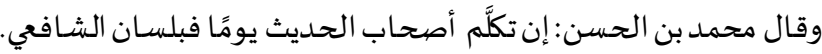

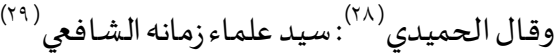

وجملة القول أنهاه من فضل الله سبحانها وتعالى على الأمة أن وهبها الشافعي ، وجمع فى شخصيه خصيائص التميز ، وفى فقهاه

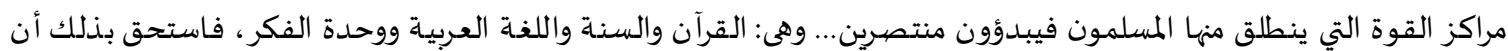
يكون ناصرًا للسنة وواضعًا للأصهول.

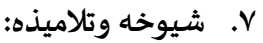

أخذ الإمام الشافعي العلم عن كثير من العلماء في مكة المكرمة، والمدينة، واليمن، والعراق، فأما الذين أخذ عنهم بمكة فهم:

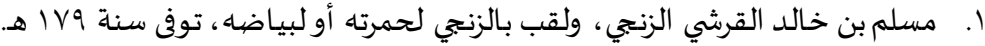

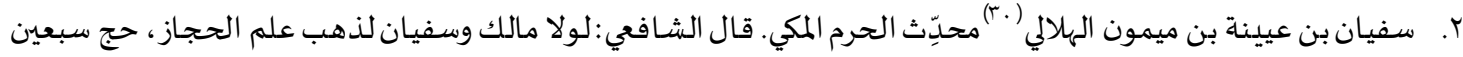

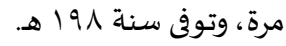

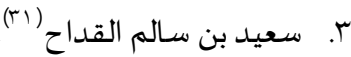

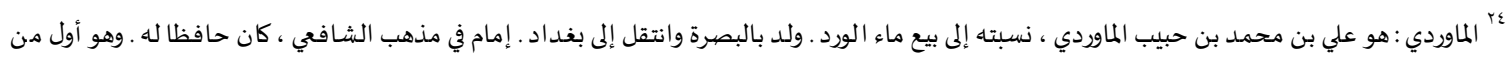

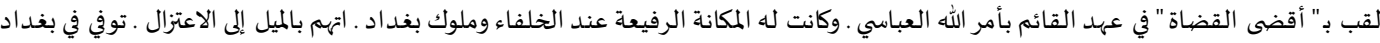

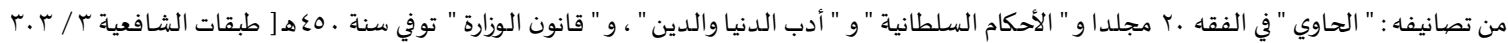

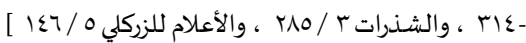

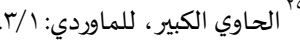

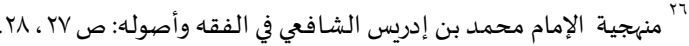

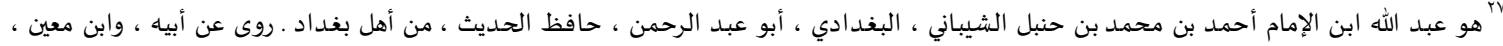

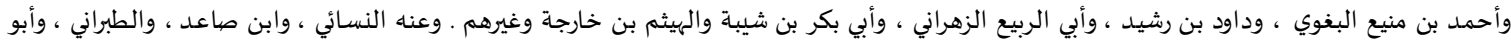

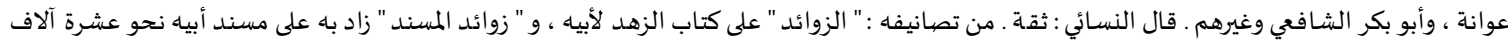

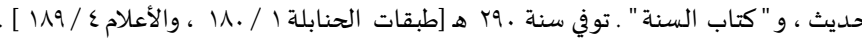

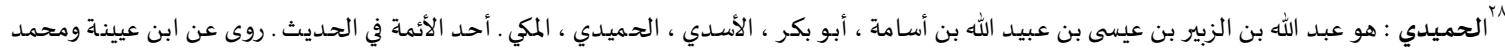

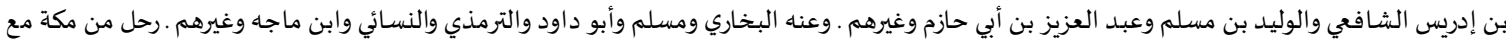

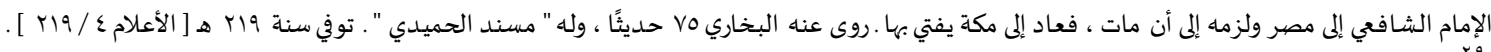

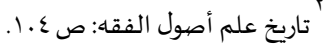

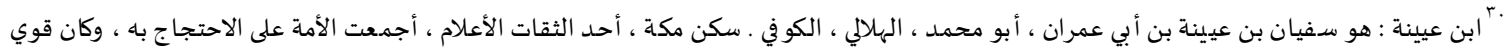

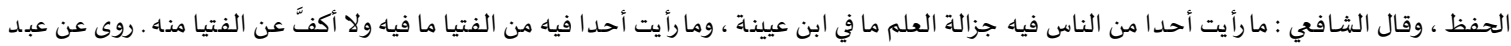

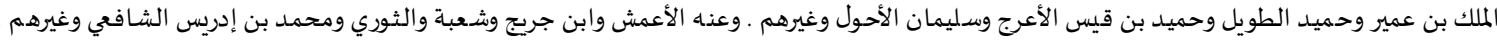

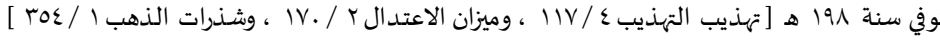

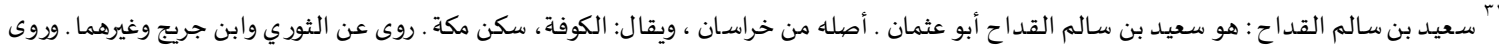

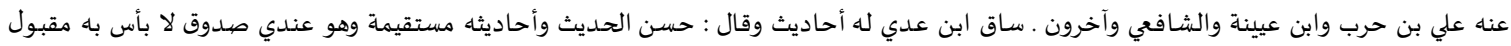

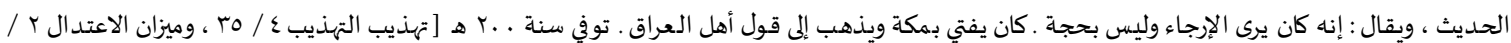


ع. داود بن عبد الرحمن العطار (rr).

وأما الذين من أهل المدينة المنورة فستة:

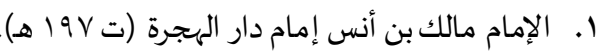

r. إبراهيم بن سعد الأنصاري.

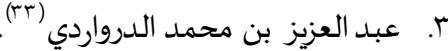

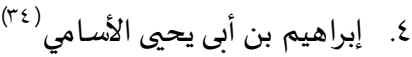

0. عبد الله بن نافع الصائخ (ب0).

وأما الذين من أهل اليمن فهه:

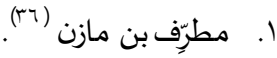

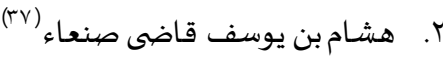

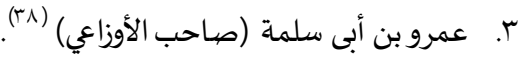

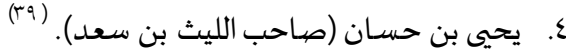

"َّاود بن عبد الرحمن العطار العبدي أبو سليمان المكي. روى عن هشام بن عروة وابن جريج ومعمر وابن خثيم وإسماعيل بن كثير المكي وعمرو بن دينار وعمرو

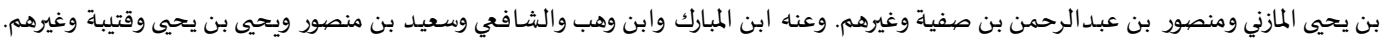

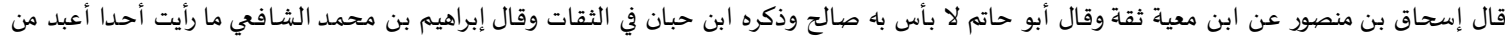

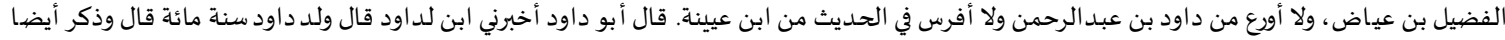

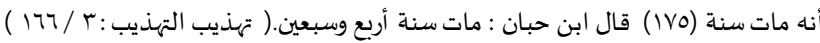

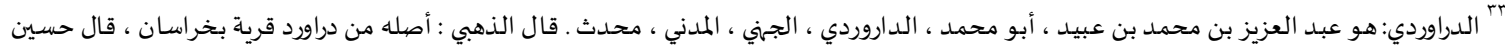
بن عيسى : يصلح أن يكون الدراوردي أمير المؤمنين.

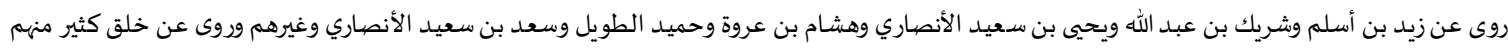

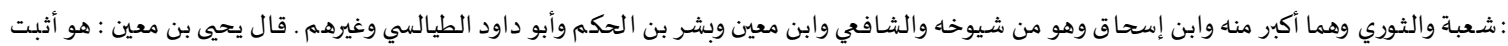

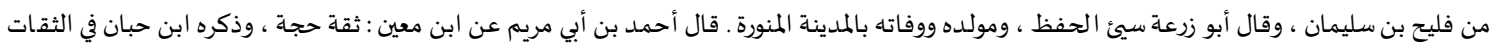

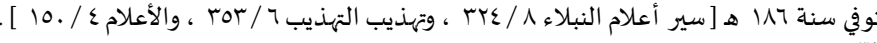

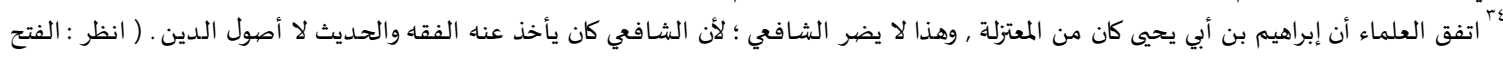

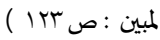

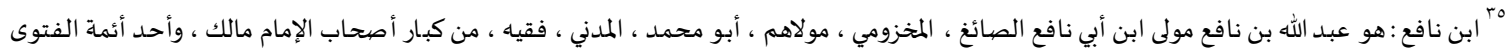

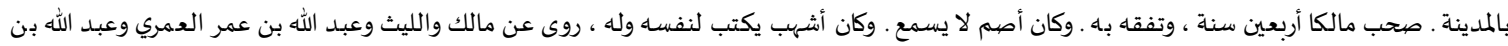

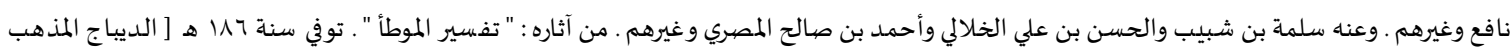

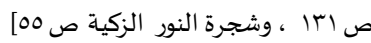

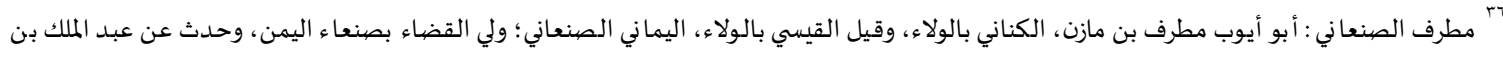

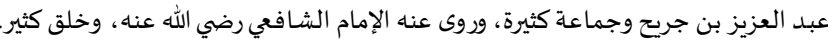

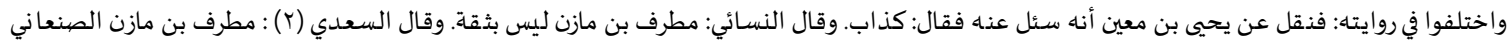

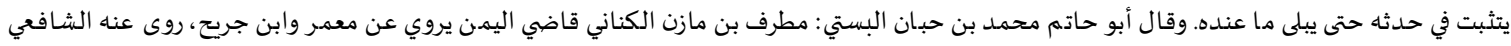

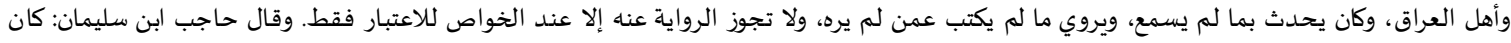

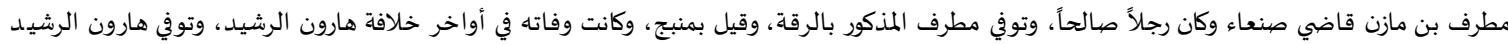

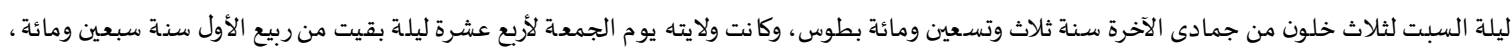

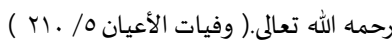

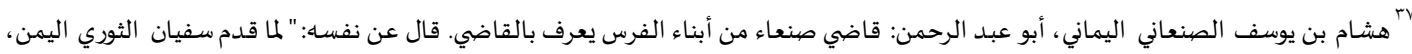

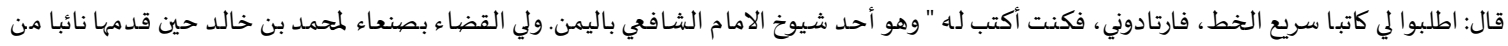

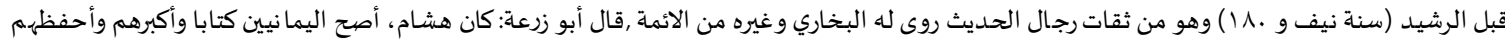

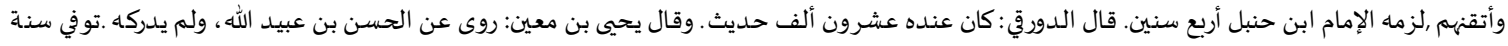

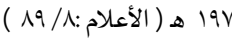

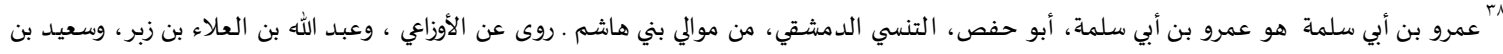

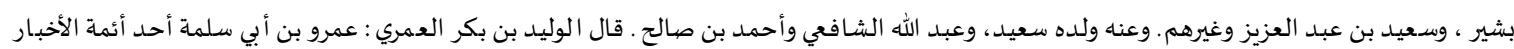

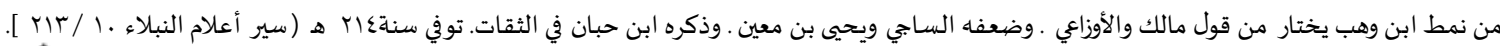




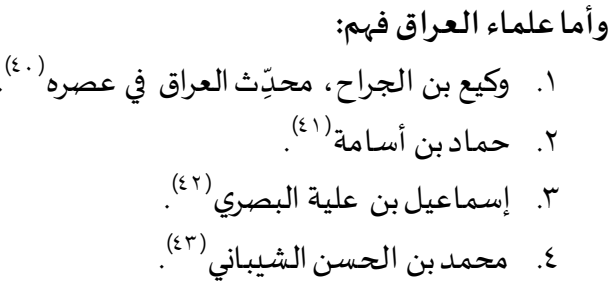

أما تلاميذ الإمام الشافعي: فقد كان له تلاميذ نقلوا فقهه في كل دور من الأدوار الثلاثة: بمكة ، وبغداد، ومصر ، ومن أشهرتلاميذه:

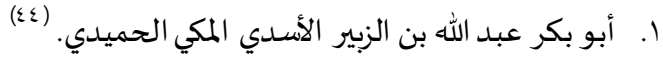

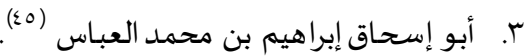
r. أبو الوليد موسى بن أبى الجارود. وهؤلاء أشهر تلاميذه بمكة المكرمة. ومن أشهر تلاميذه ببغداد:

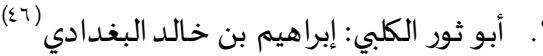

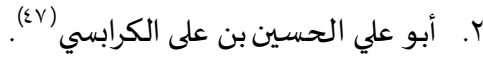

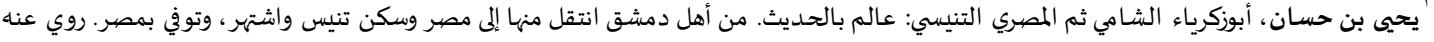

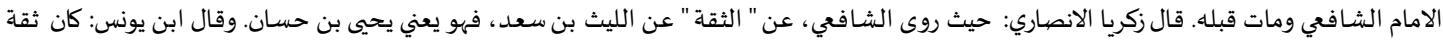

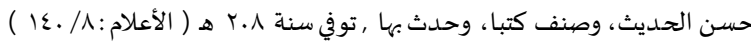

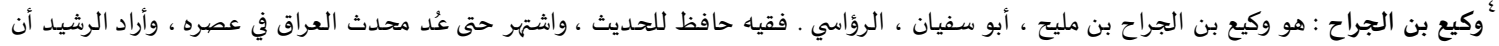

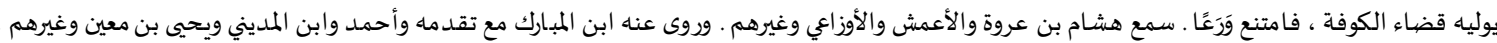

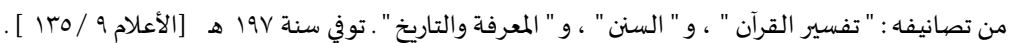

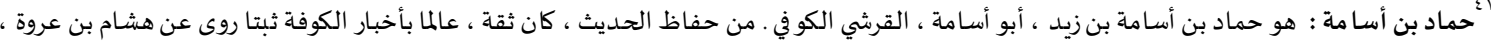

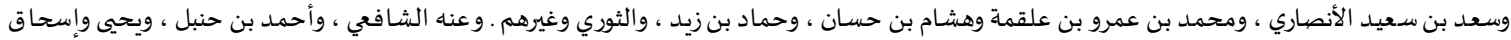

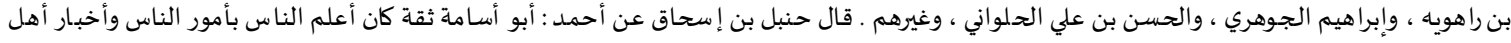

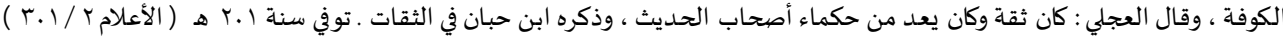

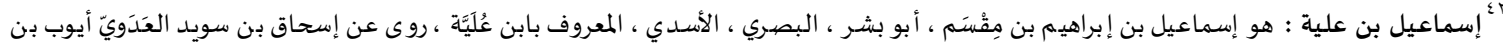

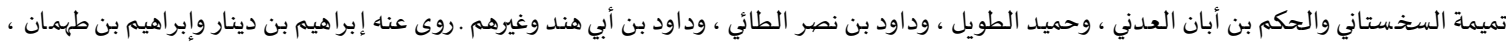

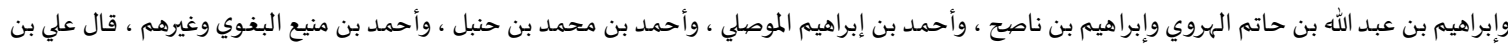

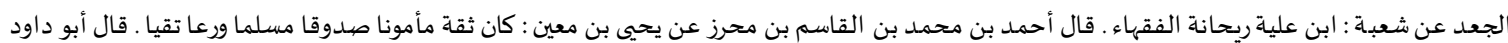

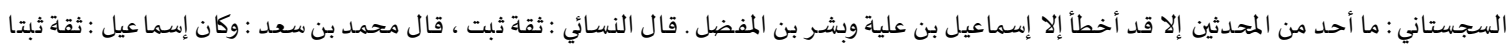

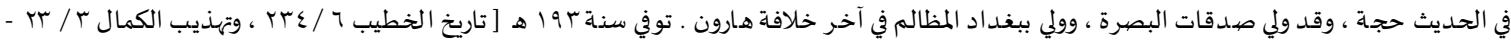

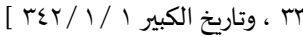

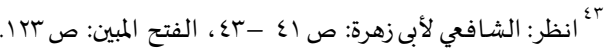
" أسبقت ترجمته

أبراهيم الإمام : هو السيد أبو إسحاق إبراهيم بن محمد بن علي بن حبر الامة عبدالله بن العباس الهاشي كان بالحميمة من البلقاء. عهد إليه أبوه بالأمر.

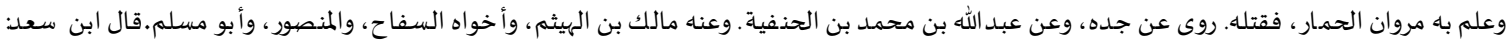

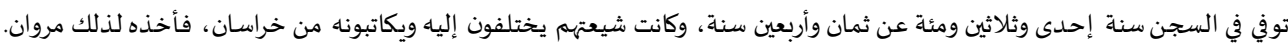

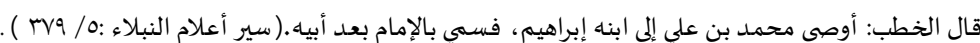

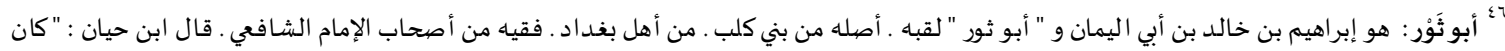

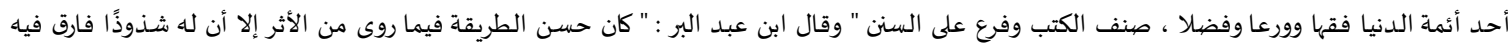

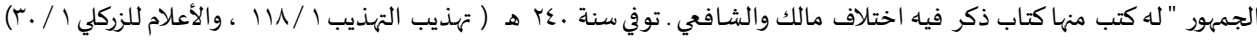

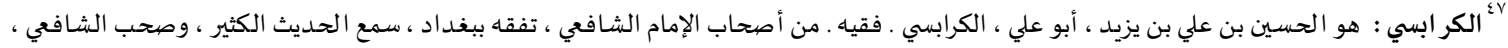

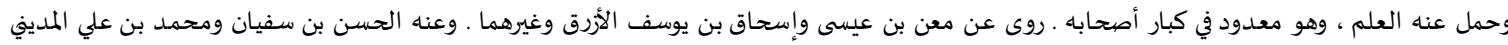

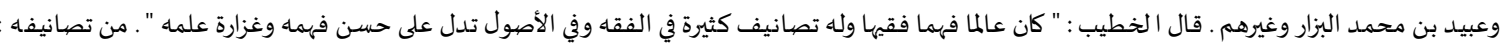

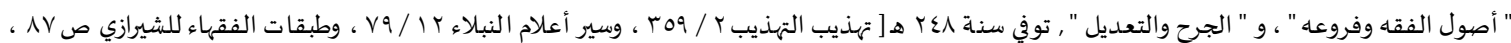




$$
\begin{aligned}
& \text { r. أبو علي الحسن بن محمد بن الحسين الزعفراني (^). } \\
& \text { ومن أشهر تلاميذه بمصر: }
\end{aligned}
$$

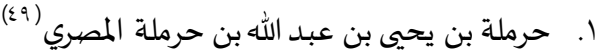

$$
\begin{aligned}
& \text { r. أبو يعقوب يوسف بن يحيى القرشي البويطي (.). }
\end{aligned}
$$

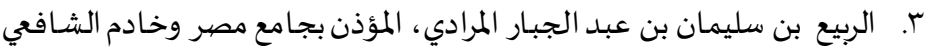

$$
\begin{aligned}
& \text { ع. الربيع بن سليمان بن داود الجيزي (1). }
\end{aligned}
$$

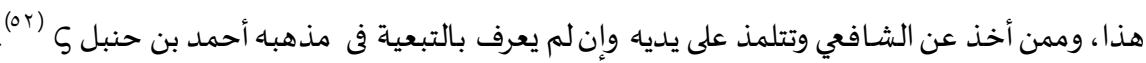

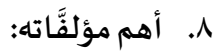

مؤلفات الإمام الشـافعي وكتاباته أكثر من أن تحصى ؛ وذلك لتفرُّهـا هنا وهناك، حملها عنها أصحابه وتلاميذه بالعراق

والحجاز ومصر.

يقول الإمام الشافعي: أنفقت ستين دينارًا على كُتُب محمد بن الحسن ، ثم تدبرتها، فوضعت إلى جنب كل مسألة حديثًا .

وكان الشافعي يملى أحيانًا، وكثيرًا ما نجد في كتاب "الأمش: أملى علينا الشـافعي.

والشـافعي أوَّل من صنَّف في علم فضيائل القرآن، فصنف "منافع القرآنش.

وله كتاب 》الأسماء والقبائل في اختلاف العر اقيينه، يذكر فيه المسائل التي اختلف فيها أبو حنيفة وابن أبى ليلى، فتارة

يختار إحداهما ويزيف الأخرى، وتارة يزيفها ويختار غيرها.

$$
\begin{aligned}
& \text { وكتاب "الأم" وهو من أجل كتبه، جمعه البويطي، ونسب إلى الربيع المرادي؛ لأنه بوبه فنسب إليه. } \\
& \text { الكتاب الجديد، وهى "الرسالة، التي كتبها بمصر. }
\end{aligned}
$$

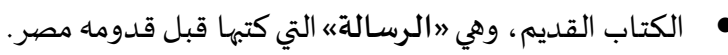

$$
\begin{aligned}
& \text { "الحجةة《، وهو كتاب الشافعي القديم في الفقه. } \\
& \text { وله 》المبسوط" في الفقه، رواه عنه الزعفراني والربيع بن سليمان. }
\end{aligned}
$$

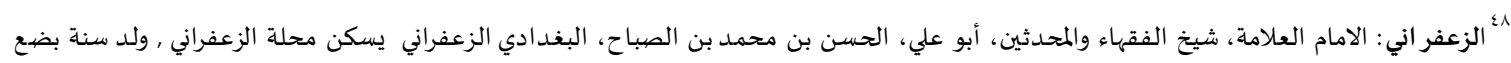

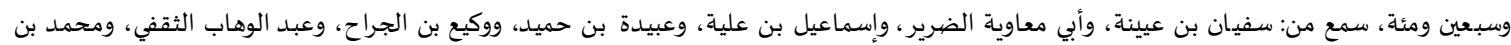

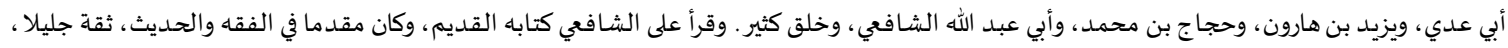

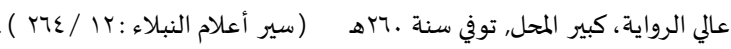

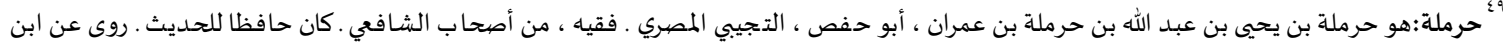

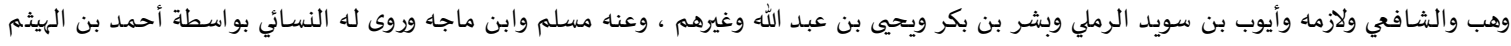

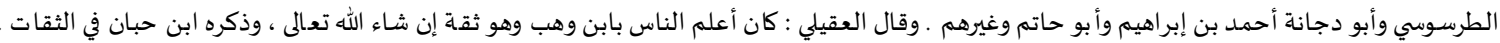

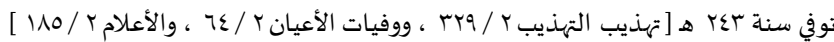

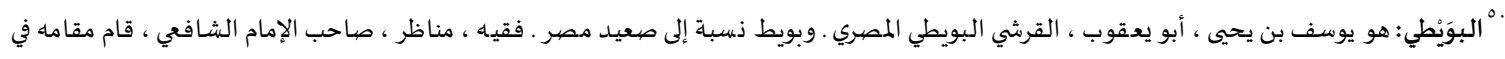

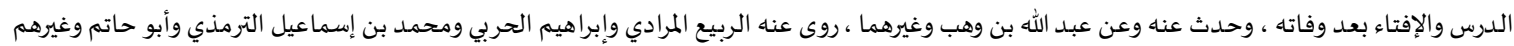

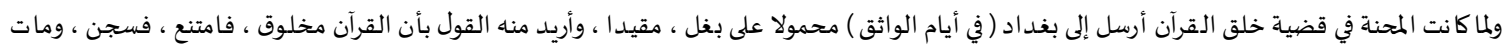

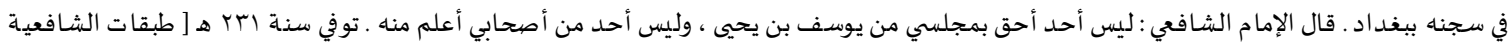

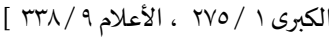

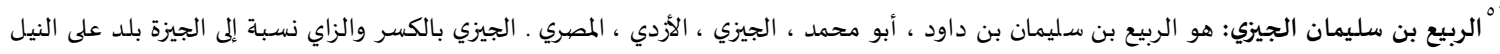

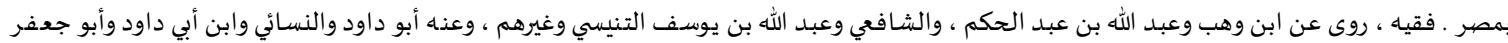

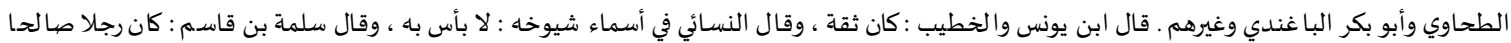

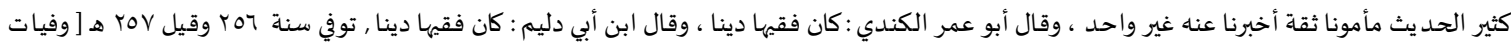

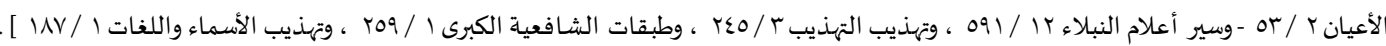

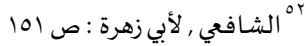
المجلة الدولية للدراسـات الإسلامية المتخصصية _ـ المجلد؟، العدد ا - 19 . ب 
هذا وغيره الكثير الذى كتبه الشـافي، أو أملاه على تلاميذه، أو جمعه تلاميذه من بعده مما هو منشور ومعلوم فى كتب التراجم والمناقب (ه).

9 . ثناء العلماء عليه:

لقد بلغ الإمام الشـافعي منزلة عالية في العلم عامة، والفقه والأصيول على وجه الخصبوص، جعلت جميع العلماء يثنى عليه بمـا هو أهله. قال الإمام أحمد بن حنبل: 》الشافعي فيلسوف في أربعة أشياء: في اللغة، واختلاف الناس، والمعاني، والفقهش.ووقال: ما أحسد ممن بيده محبرة، أو ورق إلَّا وللشافعي في رقبتاه منـة.

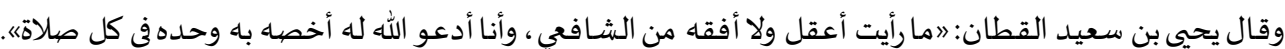
وقال عبد الرحمن بن مهدى: "لما نظرت "الرسـالة) للشافعي أذهلتني؛ لأنني رأيت كلام رجل عاقل فصبيح ناصح، فإني لأكثر الدعاء $(0 \varepsilon) \ll 4$

وأقوال العلمـاء الأعلام في عالم تعدُّ شهادات دونها كل الشهادات العلمية ، وهى دلالة على مكانة المشهود له، وبخاصة إذا كانت من أصحاب العلم والفضل، ولا يعرف الفضل لأهله إلاًّ ذووه. وبعد، فقد اتفق العلماء من أهل الفقه والأصيول والحديث واللغة على أمانة الشافعي وعدالتـه وزهده وورعاه وتقواه وعلو قدره وتواضعهه فرحماه الله رحمة واسعةة، وأنزله منازل النبيين والصيديقين والشهداء والصـالحين وحسن أولئك رفيقًا. . فى سـنة ب . r هـ أحس الإمام باقتراب رحيله إلى عالم الخلد ؛ حيث ألحَّ عليه الداء، وتجمعت عليه آثار الجهد الذى أكل جسماه، وكان نزيف البواسير يخرج مناه وهو راكب؛ حتى يملأ ثوبه وخفّه وسرجهه، ثم قويت العلة ؛ حتى ثقبوا الفراش لله، ووضعوا الطست تحتاه، وكان ك يقول: 》 اللههم إن كان لك فيه رضـا فزد《. ودنا الأجل، وأقعده المرض، وتهيَّأ للرحلة الأخيرة، دخل عليه تلميذه المزني (0) قال: كيف أصببحت؟ قال: أصببحت من الدنيا

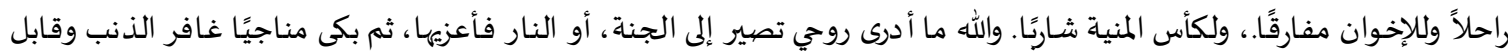
التوب سبحانه ، فقال:

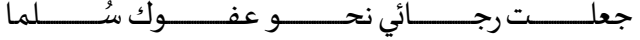

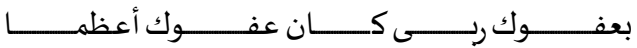

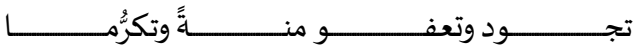

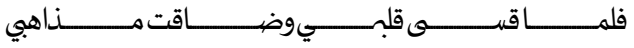
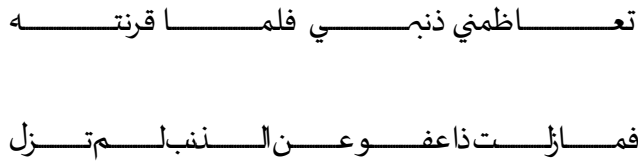

وبعدها أسلم إمام المسلمين وجهه لله ، وصعد ت روحها إلى بارئها عند العشاء الأخيرة من ليلة الجمعاة ، قالوا: حملت جنازتها إلى السيدة نفيسة وصلت عليه صلاة الجنازة وقالت: رحمه الله الشـافعي. إنه كان يحسن الوضيوء《. ودُفن جثمانه يوم الجمعة بعد صاة العصر يوم qr من رجب سنة ع . r هـ في المقطم بمقبرة القرشيين بجوار قبور بنى عبد الحكم (07) رحماه الله رحمة واسعة جمانه. وبعد، فهذا قبس يسير من سيرة إمام الفقه والحـديث، وصياحب النسب الشريف - محمد بن إدردس الشـافعي، جعلته توطئة لتحليل منهجـاء في كتابه 》الأمه ، لعل فياه ما يفتح المغاليق، وييسر سبل الفهم، ويكون عونًا لي على ولوج بحر الفقه الذى لا ساحل له.

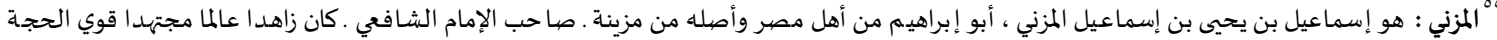

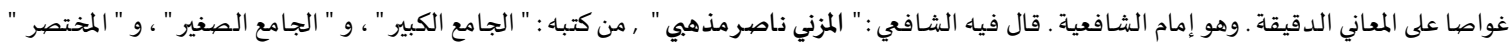

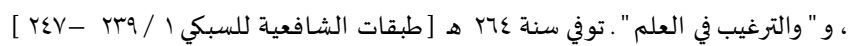

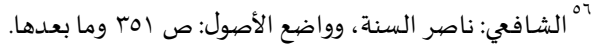


المطلب الثاني:كتاب الأم وأهميته في المذهب الشـافعي

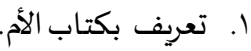

r. نسبة كتاب الأم للشافعي.

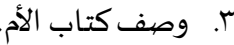

ع. أهمية كتاب الأم في المذهب الشافعي.

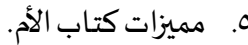

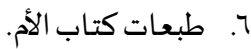

المطلب الثاني: كتاب الأم وأهميته في المذهب الشـافي

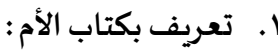

لم يعرف لإمام غير الشـافعي نشر مذهبه بنفسـه، وكتب كتبه بنفسـه ، فغيره من الأئمة قامت تلاميذهم بتدوين آرائهم ونشر

مذاهبهم.

أما الإمام الشافعي فقد استقل بطريقته في الاجتهاد والبحث والفتيا، وبعد ذلك أخذ يؤلف الكتب ، ويدون المبادئ التي

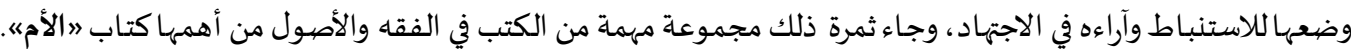

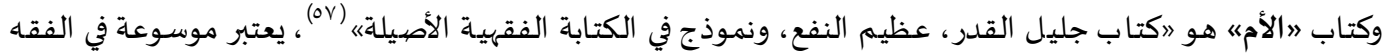

الإسلامي، وضع فيه الإمام الشـافعي خلاصهة الأحكام الفقهية التي استقر عليها بعد حله وترحاله بين الحجاز والعراق ، ثم استقراره في

نهاية المطاف بمصر.

وكتاب "الأمه شأنه شأن مصنفات الإمام الشـافعي - جميعها - كتب القسم الأكبر مناه بقلمه، وهو ما قرأه عليه تلاميذه،

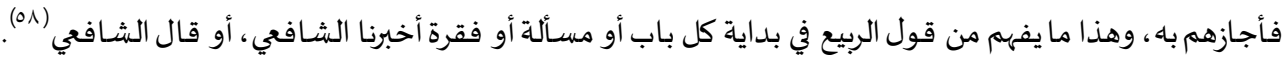

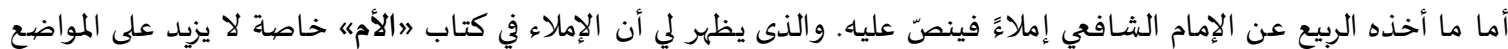

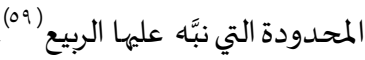

وجملة القول: إن كتاب "الأمه من أشهر مصنَّفات الإمام الشافعي أَلَففه في مصر آخر حياته، ورواه عنه تلميذه الربيع بن

سليمان المرادي ، وفيها تمثيل لقوله الذى استقر عليه مذهبه، وهو بحق من أجل الكتب التي عرضهها تراثنا الفقهي، ويُعتبر مفخرة من

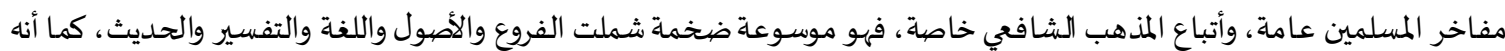

حوى بين دفتيه عددًا هائلاً من الأحاديث والآثار وفقه السلف رحمههم الله تعالى.

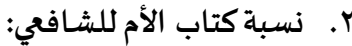

على الرغم من إجماع الباحثين في تاريخ التشريع الإسلامي على نسبة كتاب "الأمب إلى الإمام الشـافعي إلَّا أن بعض المشككين

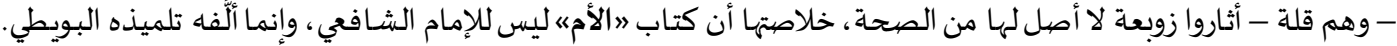

وحمل لواء هذه الفرية الدكتور زكى مبارك في كتاب: (إصلاح أشنـع خطأفي تاريخ التشريع الإسلامي، كتاب الأم لم يؤلفه الشافعي، وإنما

ألفه البويطي، وتصرف فيه الربيع بن سليمانه (. (7).

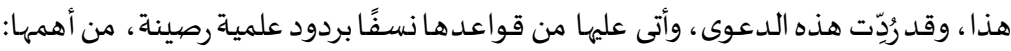

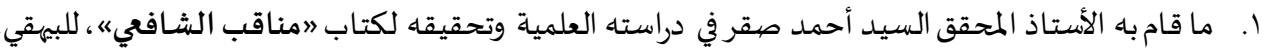

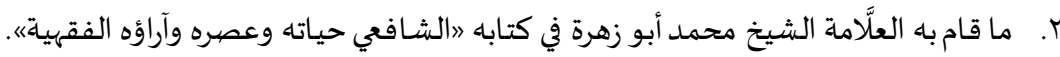

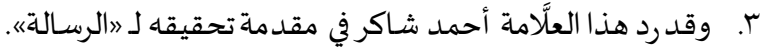

وجاء في توالى التأسيس، لابن حجر : اقال الربيع: أقام الشافعي هاهنا - أي في مصر - أربع سنين، فأملى ألثًا وخمسمائة

ورقة ، وخرج 》الأم《 ألفى ورقة.

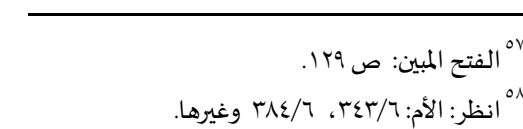

9 ألمدخل إلى مذهب الإمام الشافعي ط دار النفائس.

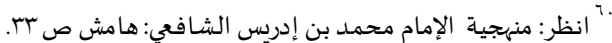

المجلة الدولية للدراسات الإسلامية المتخصصة _ـ المجلد؟، العدد ا - 19 . 
وفي موضع آخر : "وكان يضع الكتاب بين يديه، ويصنف ، فإذا ارتفع له كتاب جاءه ابن هرم فكتب ويقرأ عليه البويطي وجميع

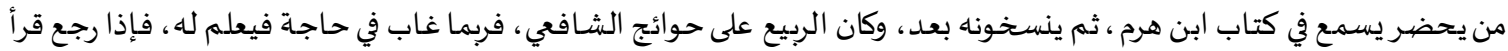
الربيع عليه ما فاتها" (11)

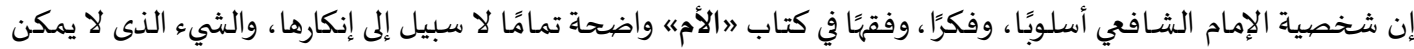

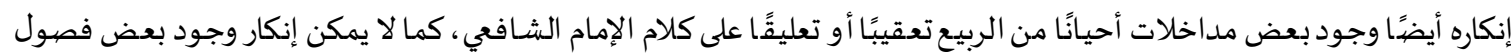

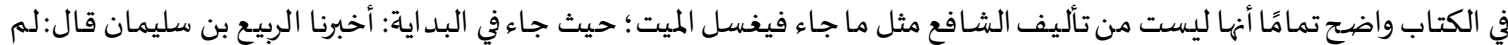

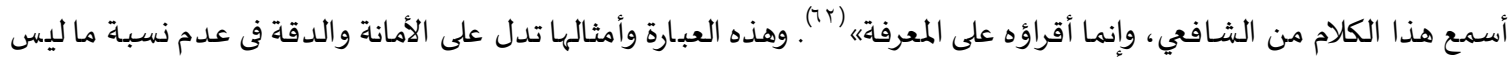

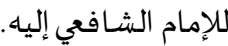
وبالرغم وجود هذه المداخلات والإضافات فإن هذا لا يبرر إنكار صحة نسبة الكتاب للإمام الشافعي، ولا تهض دليلاً نسبة

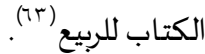

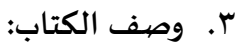

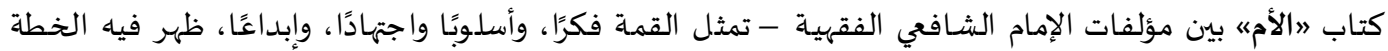

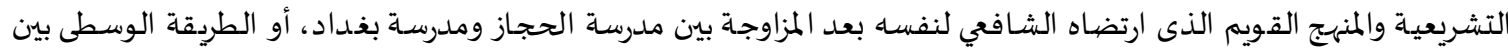

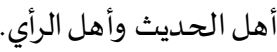

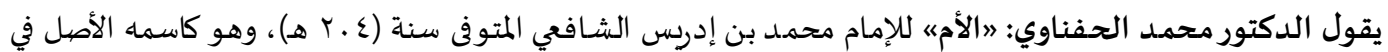

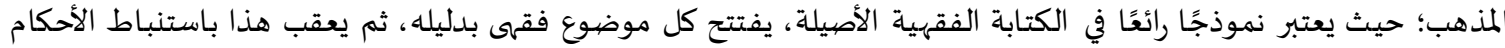

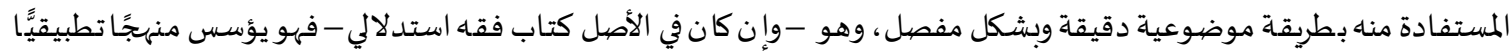

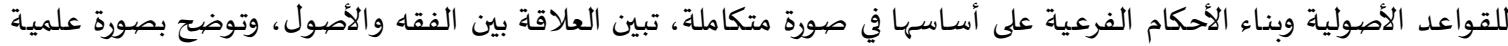

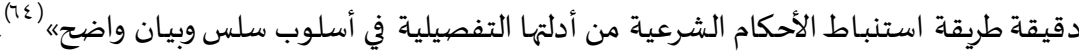
نموذج تطبيقي من "الأمش؛ وهذا نموذج لهذا النهج الذى سلكه الإمام الشافعي، قال رحمه الله تعالى في كتابه 》الأم|؛: الطهارة: أخبرنا الربيع بن سليمان

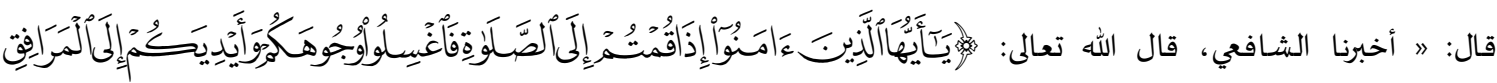

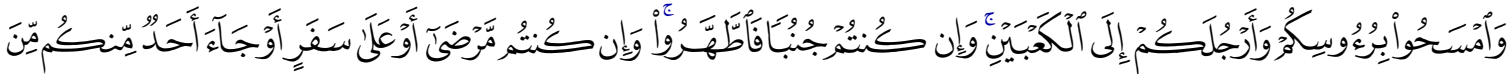

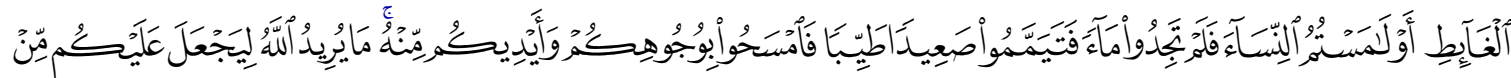

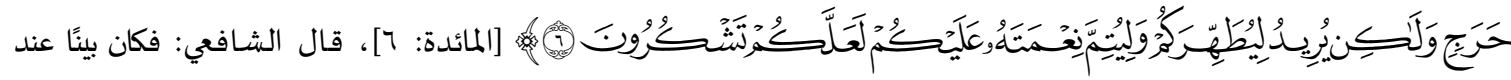

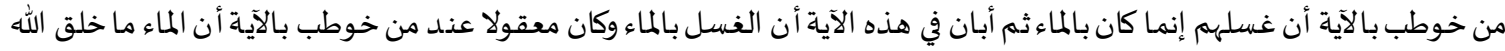

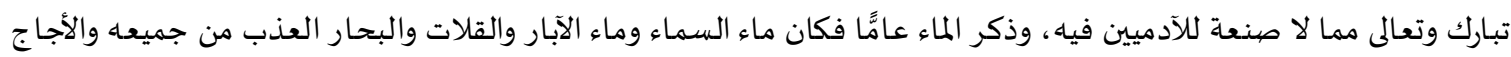

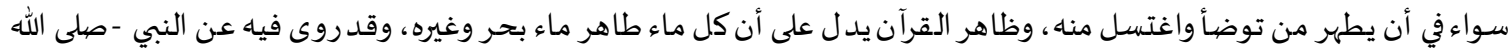

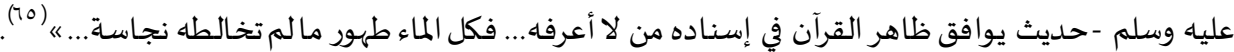

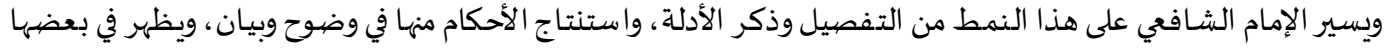


وهو كتاب - وإن كان يمثل فقاه الشافعي خاصة في الفقه، حوى كثيرًا من المسائل الخلافية. وطريقته في تناول كل هذه

المسائل تربى بلا شك الملكة الفقهية الاجتهادية لدى طلاب العلوم الشرعية والباحثين فهيها (77).

$$
\text { ع. أهمية كتاب "الأم《 في المذهب الشافعي: }
$$

ذكر العلماء أن كتب الإمام الشافعي التي صنَّفها في الفقه أربعة: الأم -الإملاء - مختصر البويطي - مختصر المزني.

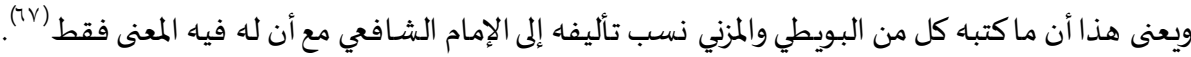

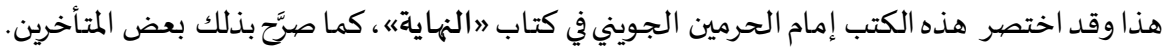

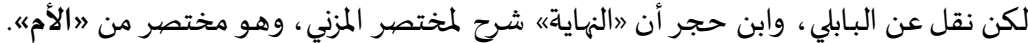

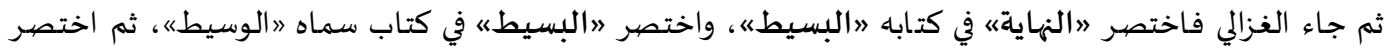

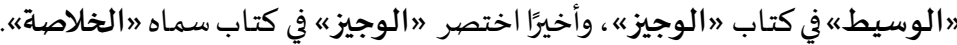

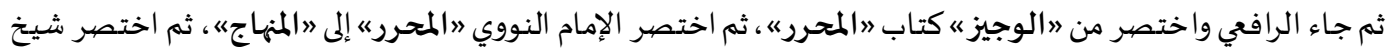

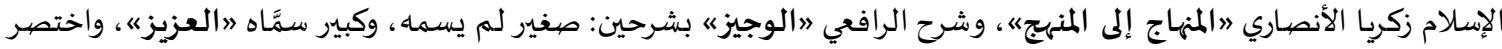

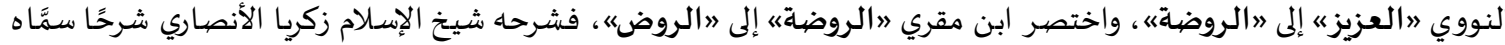

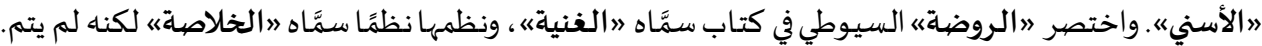
وهكذا تستمر هذه السلسلة الذهبية في عقد كتب المذهب الشـافعي، والتي كانت نواته هـ كتب الإمام وبخاصية 》الأمبه، مما

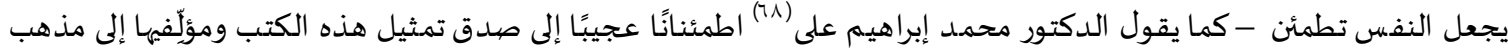
الشافعي (79)

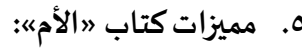

ميَّزت كتاب "الأمه للإمام الشافعي مجموعة من السمات، جعلته في مصاف المقدمة بالنسبة للتراث الإسلامي، ومنها على سبيل المثال:

1. أنها من أقدم المصنَّفات الجامعة لعلوم الفقاه الإسلامي.

r. أنهاه حوى الكثير من النصوص والأحاديث والآثار.

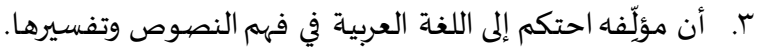

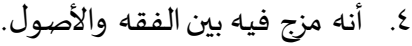

0. أنه حوى كثيرًا من القواعد والضيوابط الفقهية.

7. أنه اشتمل على مناظرات ومناقشات علمية دقيقة.

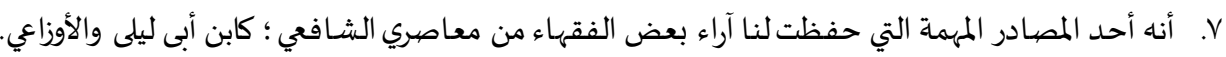

^.أنه حوى كثيرًا من فقه المشهورين من الصحابة ؛ كأبي بكر وعمر وعلى أجمعين.

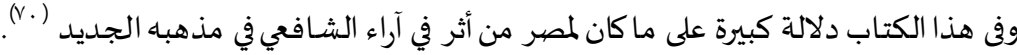

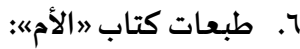

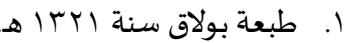

r r طبعة دار الشعب بمصر، وهى مصيورة عن طبعة بولاق، وبها مشها لهختصر المزني".

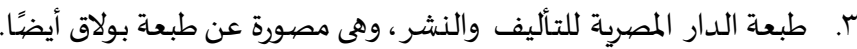

ع. طبعة الدار العلمياة.

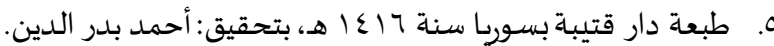

"جأعرض بالتفصيل - إن شاء الله تعالى - لأهم معالم فكر الشافعي الفقهي في المبحثين الثاني والثالث من هذا البحث، مع ذكر الأمثلة التطبيقية لكل معلم

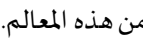

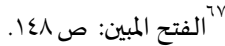

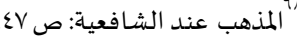

الفتح المبين: ص .10.

×.انظر: مقدمة الأستاذ حسن عباس زكى لكتاب " الأم « ط: دار الشعب.

المجلة الدولية للدراسات الإسلامية المتخصصة _ـ المجلد؟ب، العدد ا - 19 


$$
\begin{aligned}
& \text { 7. طبعة دار المعرفة - بيروت سنة بهو ا هـ، بإشراف محمد زهري النجار. }
\end{aligned}
$$

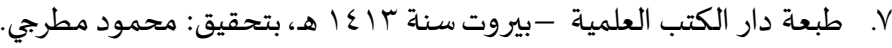

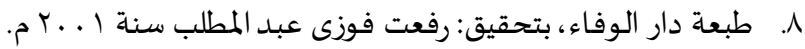

هذا، وتعتبر طبعة دار الوفاء بتحقيق الأستاذ الدكتور /رفعت فوزى عبد المطلب هى أفضل الطبعات ؛ لأها مدققة ومقابلة على نسخخ خطية مع خدمة النص بالترقيم والتخريج والفهارس المتنوعة.

\section{المبحث الثاني: المعالم العامة لمنهج الإمام الشـافعي في كتابه 》الأم《ه وفيه:}

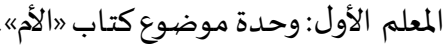

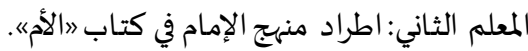
المعلم الثالث: وضع عناوين لكل باب من أبواب الفقاه.

المعلم الرابع: البدء بالقرآن الكريم واستقراء آياته. المعلم الخامس: استقراء السُنّْة النبوية ومكانتها في التشريع.

المعلم السادس: الأخذ بفتاوى الصحابة والاختيار منها.

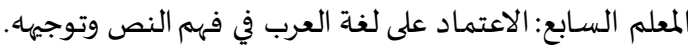

المعلم الثامن: الأخذ بالإجماع وفق مفهوماه عند الإمام.

المعلم التاسع: الاعتماد على القياس والتوسُّع فياه. المعلم العاشر: ضبط الفروع والأحكام بالقواعد الفقهية الاعبية والأصيولية.

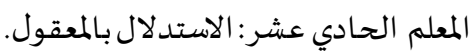
المعلم الثاني عشر: مراعاة الإمام للأعراف والبيئات.

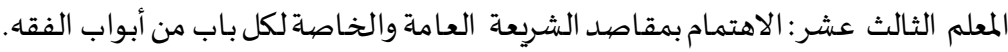

المعلم الرابع عشر: اعتماد الإمام الخلاف العالي (الفقه المقارن). المعلم الخامس عشر: التزاوج بين الفقه والأصيول. المعلم السـادس عشر: عدم التوسع في الفقه الافتراضي. لمعروسي. المعلم السابع عشر: العناية بالنوازل والمستجدات المعات الفقهية. المعلم الثامن عشر: بناء الأحكام والفتاوى على الجمع والترجيح والاختيار والانفراد الفقهي.

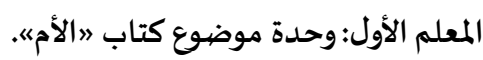

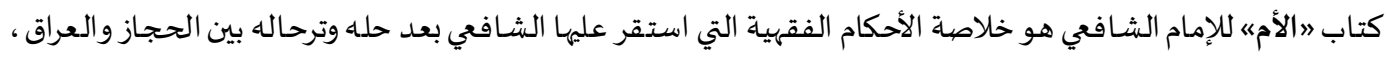

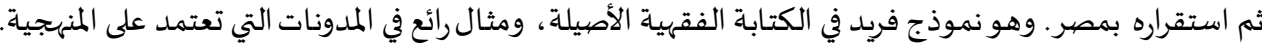

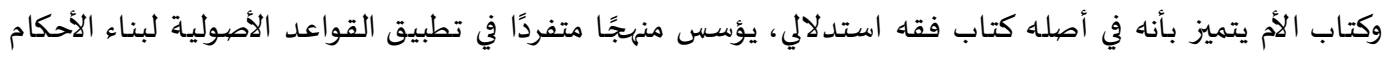

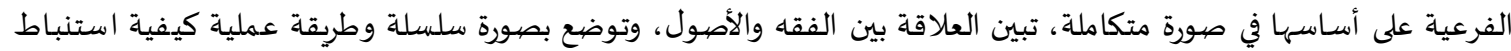

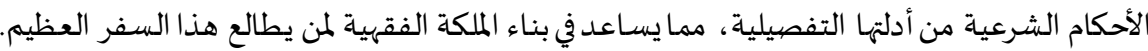

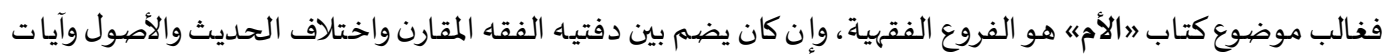

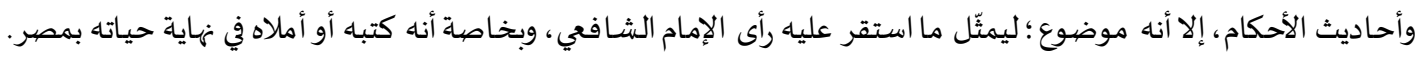

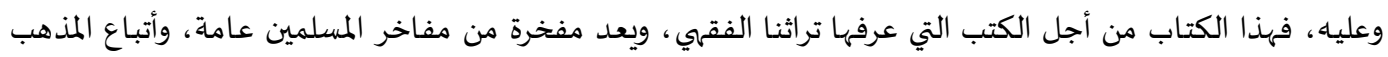

الشـافي على وجع الخصوص، فهو موسوعة الفقه التي نهل الجميع منها.

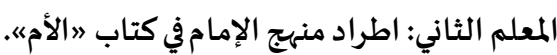

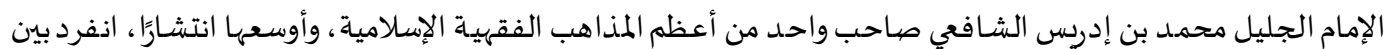
الأئمة العظام بتدوين فقهاه وأصوله بأسلوب ومنهج غير مسبوقين ( (v).

" المنهجية الإمام محمد بن إدريس الشافعي: ص 9. المجلة الدولية للدراسات الإسلامية المتخصصة _ـ المجلد؟، العدد ا - 19 
وعليه، فيمكن القول: إن أهم ما يميز أعمال الشافعي -وكلها ميزات - هو المنهج المطرد في الكتابة الفقهية والأصهولية، وقد ظهر ذلك

جليًا في كتاباه 》الأم" حيث إناء:

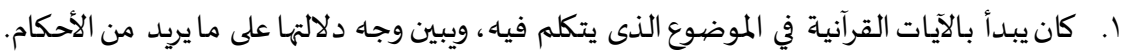

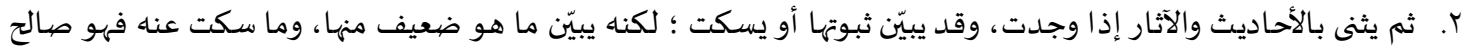

r. ثم يتكلم عن فروع الباب، وما يُستنبط فيه من أحكام بناءً على الأدلة وقواعد الأصهول، وقد يتخلل ذلك بعض القواعد.

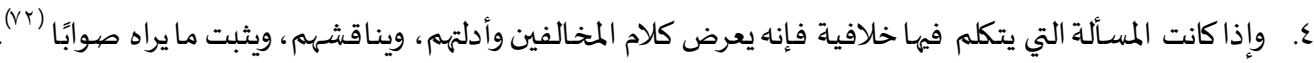

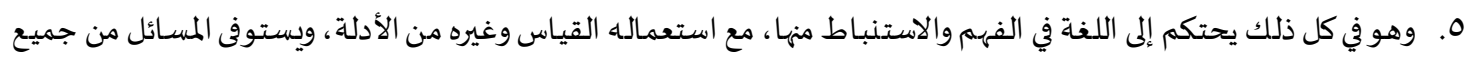

جوانها ؛ ليصل إلى الحكم الفقهي ؛ وذلك مطرد في الكتاب كله.

المعلم الثالث: وضع عناوين لكل باب من أبواب الفقه.

من المفاخر التي يتشـدق بها علماء الغرب المعاصرون مسألة التبويب والفهرسة للمؤلَّفات، ويزعمون أهنا من بنات أفكارهم،

وهم السابقون في ابتداعها.

والحق الذى لا مراء فيه أن تبويب المؤلَّفات عمل سبق إليه المسلمون الأوائل ،ورأينا ذلك في كثير من المخطوطات العربية في

$$
\text { علوم الشريعة وغيرها من علوم العبية. }
$$

وهذا إمامنا الشافعي يبدأ موضوع الفقهاه بوضع عنوان عام للموضهوع، ثم يضع العناوين الفرعية المتعلّقة بهاه، حتى

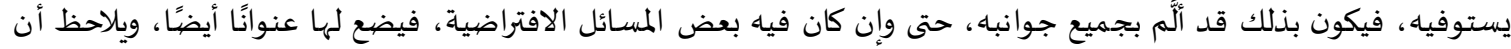

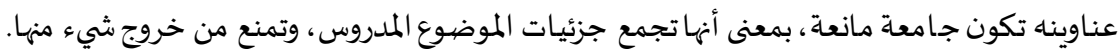

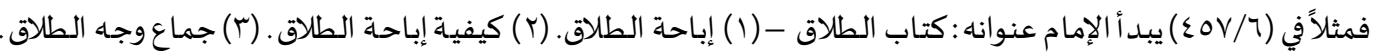

(ع) تفريع الطلاق... وهكذا إلى ( . 1) الطلاق بالحسـاب. وهكذا في الكتاب كله.

ولله در القائل: انظرت في كتب هؤلاء النابغة الذين نبغوا في العلم، فلم أر أحسن من المطلبي ، كأن فاه نظم درًا إلى درٍِ (Vr). المعلم الر ابع: البدء بالقرآن الكريم واستقراء آياته.

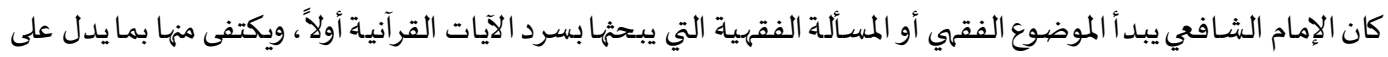
القضية المطروحةة، أو يعالج جانبًا فقهيًّا لله علاقة بها. دون استكثار بسرد الآيات في الموضيوع إذا كان بعضهها أدل من الآخر ، ودون

اقتضياب لما هو لازم للاستدلال.

وفي الموضوعات أو المسائل التي تحتاج إلى جميع النصوص القرآنية الواردة فيها، فإنها لا يألوا جهدًا في ذكرها وجمعها، ولا

يتجاوز هذه الخطوة إلى استقراء والسنة أو التعريج على اللغة إلا بعد جمع الآيات والترجيح والتعليق عليها.

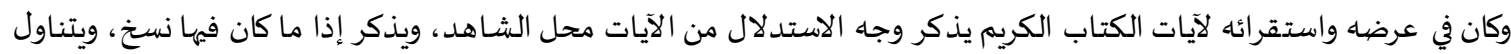
الظاهر والعام ودلالات الأمر والنهى فهها إلى غير ذلك مما سنذكره مفصلاً في المبحث الثالث من هذا هذا البحث.

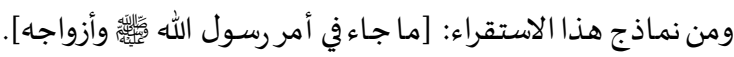
قال الشـافعي: إن الله تبارك وتعالى لما خصّ باء رسوله من وحياه، وأبان من فضله من المباينة بينه وبين خلقاه بالفرض على

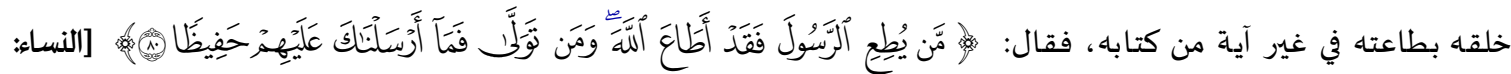
.

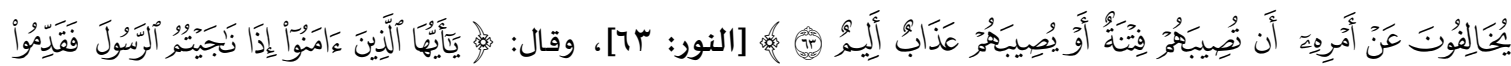

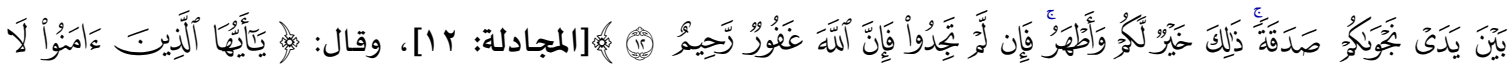

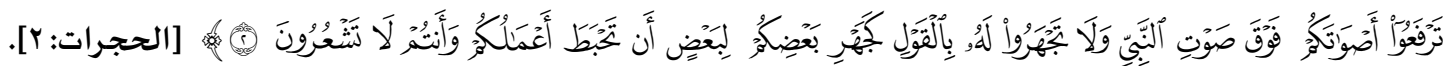


قال الشـافعي: افترض الله على رسوله أشياء خففها عن خلقها ليزيده بها - إن شاء الله - قربة إليه وكرامة، وأباح له أشياء

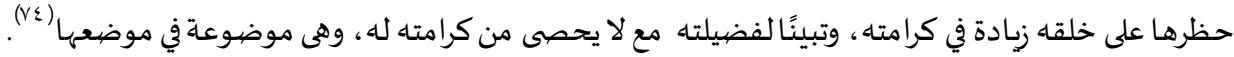

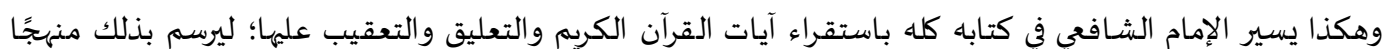

مطردًا قلَّ أن نجد له نظيرًا.

المعلم الخامس: استقراء السُّنَّة النبوية ومكانتها في التشريع.

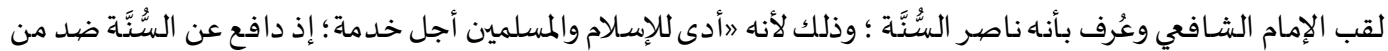

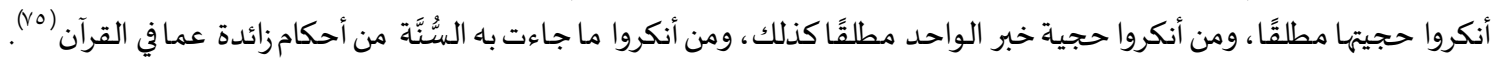

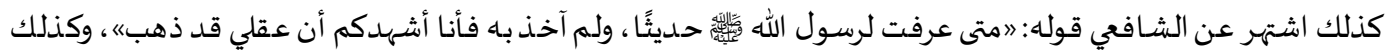

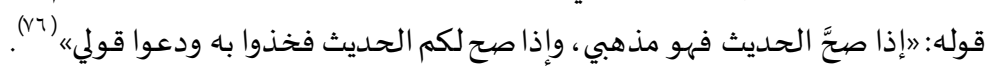

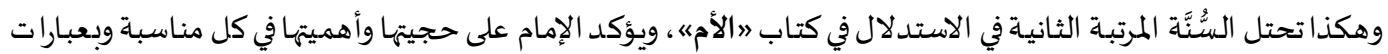
مختلفة مثل قوله: 》لا يحل عندي خلاف الحديث" (VV). وكان الإمام الشـافعي في كتاب " الأمه بعد أن يذكر الآيات في المسألة الفقهية المدروسة ، ويثنى بالسُّنَّة النبوية المطهرة، يقول:

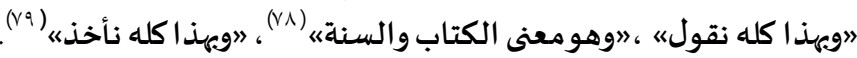

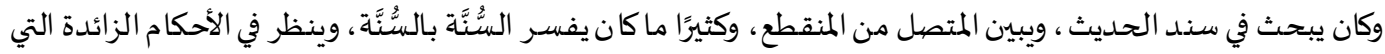
تأتى بها السُّنَّة كتحريم الجمع بين المرأة وعمتها، والمرأة وخالتها.

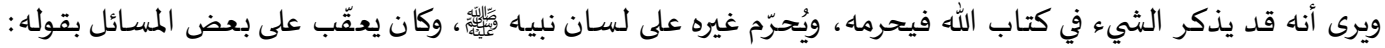

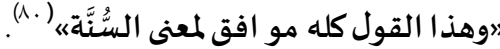

يقول الدكتور عبد الوهاب أبو سليمان: ليقتضى المنهج الفقهي عند الإمام الشافعي عند الاستدلال بالسُنَّنَّة الخطوات التالية:

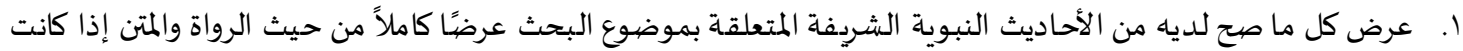

متفقة

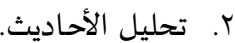
r. استنباط الأحكام الفقهية من جملة الأحاديث النبوية. ع. وفى حالة التعارُض بين الأحاديث التي صحت عنده في موضوع البحث، فإنهاه يثبت المعارض الذى صحت روايتاه ويفصح في عبارة مؤدبة، وبطريقة مهذبة ما يشعر أخذه بأحدهما لو تحقق ثبوته ورجحانه على الآخر. ويبين بعد هذه الآثار الشرعية

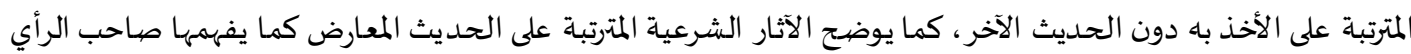

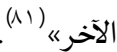

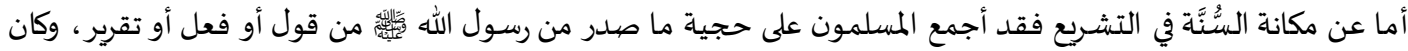

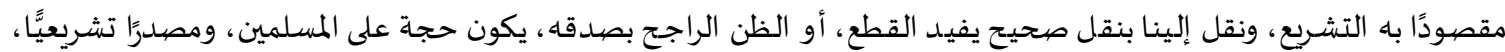

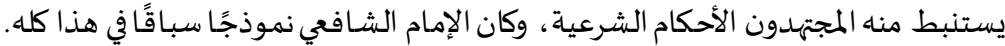

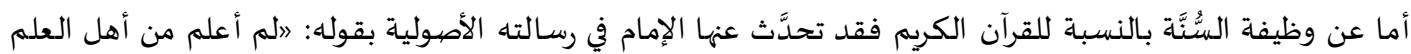

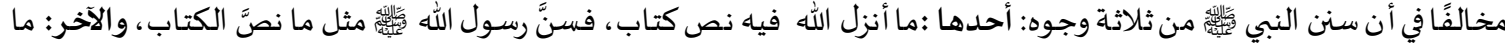

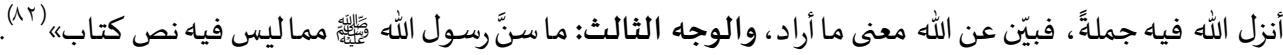

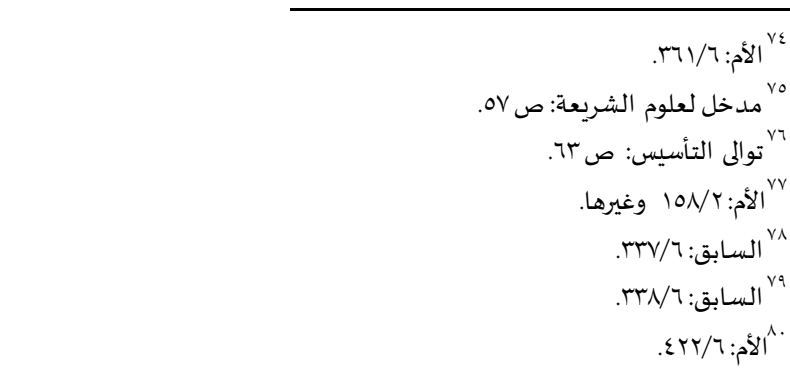

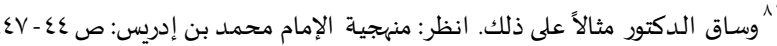

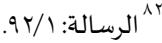

المجلة الدولية للدراسات الإسلامية المتخصصية _ـ المجلدب، العدد ا - 19 ب r 
هذا، وقد طبَّق الإمام الشـافعي وظائف السُّنَّة هذه في كتابه 》الأمه خير تطبيق، وجمع، ورجّح، واختار؛ بل انفرد في كثير من

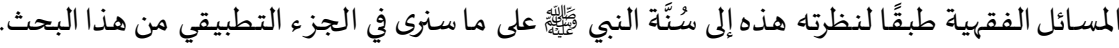

المعلم السـادس: الأخذ بفتاوى الصحابة والاختيارمنها.

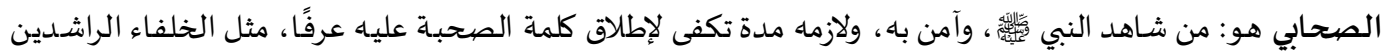
وابن مسعود وابن عباس وغيرهم.

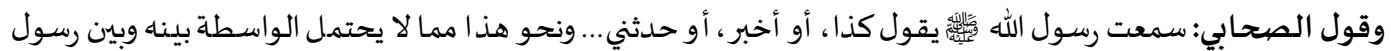

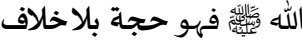

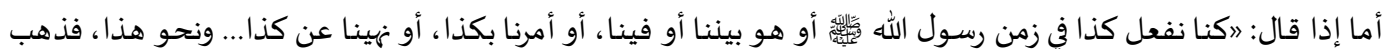

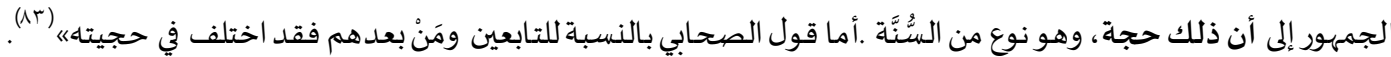

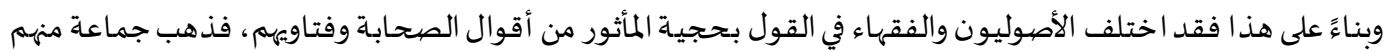
إلى القول بحجيتها، ونقل عن الشـافي قوله: 》 ما كان الكتاب والسنة موجودين فلا عذر في العدول عنهما، فإن لم يكونا صرنا إلى إلى أقاويل الصحابة أو واحد منهم , وقول الأئمة : أبي بكر وعمر وعثمان أحب إلينا إذا صرنا إلى التقليد ؛ لأن قول الإمام مشهور يلزم

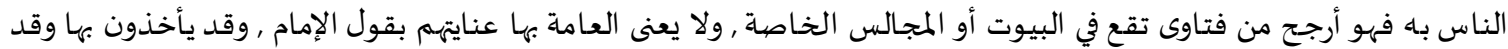

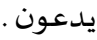
كل ذلك إذا لم يتضـمن الاختلاف بين الصحابة دليلاً على ما هو الأقرب إلى الكتاب والسُّنة من آرائهم، والا اتبعنا القول

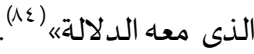
أما جمهور العلماء فذهبوا إلى أن أقوال الصحابة ليست بحجة، وعليه جمع من متأخري المذاهب الأربعة (10) ومن تتبع جزئيات كتاب "الأمه نجد أن الشـافعي كان يختار من أقوال الصحابة المختلفة في الفروع - وذلك فيما هو مجال للاجتهاد

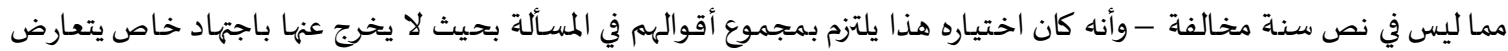

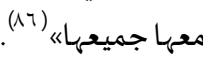
وجملة القول أن الإمام الشـافعي كان يعرض في بعض مسائله لآراء الصحابة وفتاويهم ومخالفتهم، ويختار من هذه الآراء ما

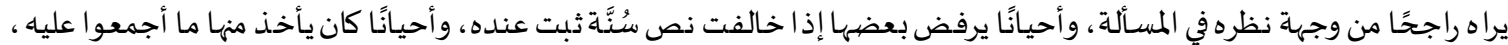

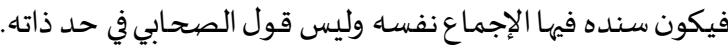
وجملة القول :»إننا نود فقط أن نبدى ملاحظة بسيطة، وهى أنها من الواضح جدَّا أن الإمام الشافعي من الناحية

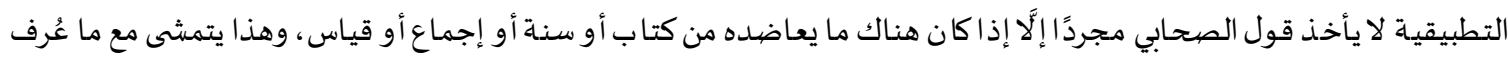

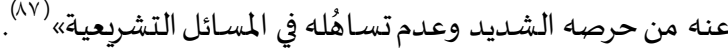
المعلم السابع: الاعتماد على لغة العرب في فهم النص وتوجيهه.

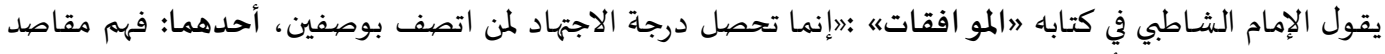

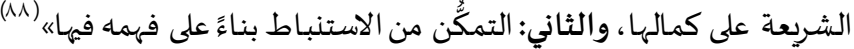
فاللغة العربية هي اللسان الذى نزل باء القرآن العظيم، ونطق بها خير الخلق أجمعين، وهى المعين على فهمم النصوص

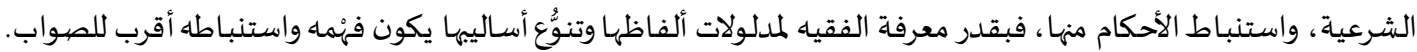

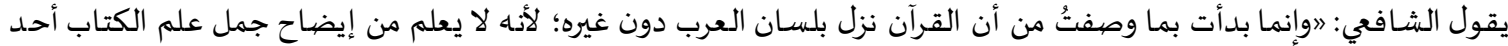

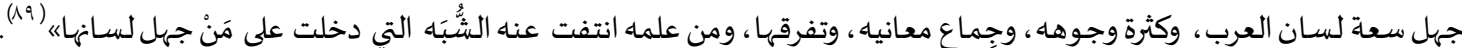

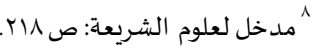

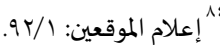

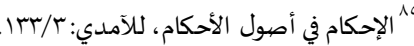

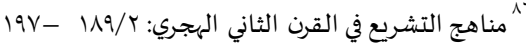

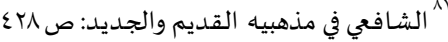

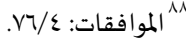

$$
\begin{aligned}
& \text { (الرسالة: }
\end{aligned}
$$


وعليه، فقد كان الإمام الشافعي يبدأ بتحديد المقصيود من النص لغويًا، ثمى يستشهد له بما يؤيده من آثار وأخبار، فإذاذ

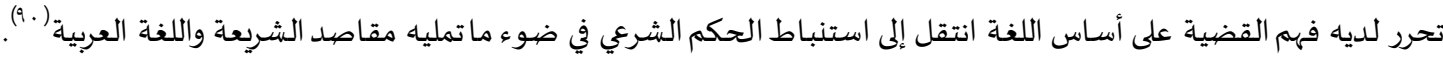
هذا، وسوف نذكر في المبحث الثالث من هذا البحث الجانب التطبيقي لاعتماد الشافعي للغة في الاستنباط؛ وذلك تجنُبًْا للتكرار.

المعلم الثامن: الأخذ بالإجماع وفق مفهومه عند الإمام.

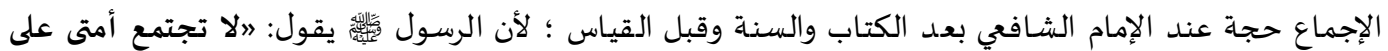

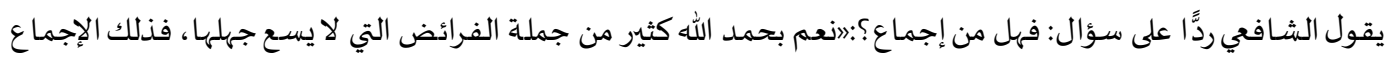

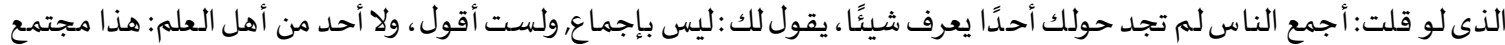

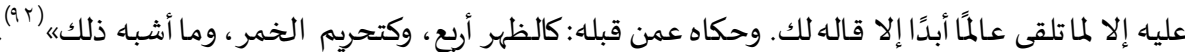

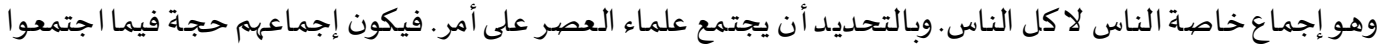

والإجماع السكوتي ليس إجماعًا؛ لأنه لا ينسب لساكت قول، كما يقول الإمام الشافعي.

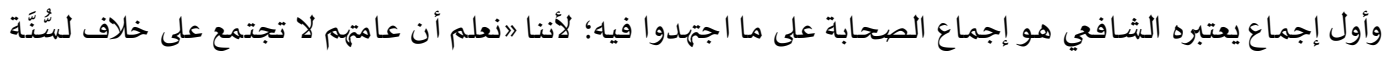

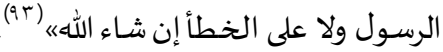

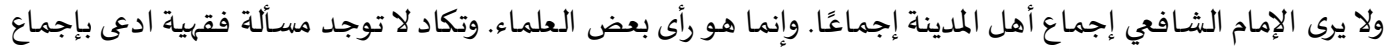

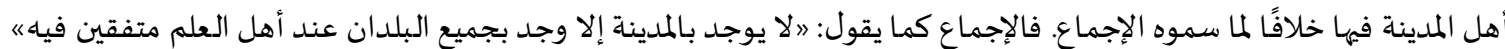

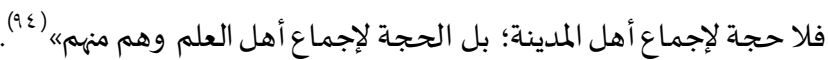

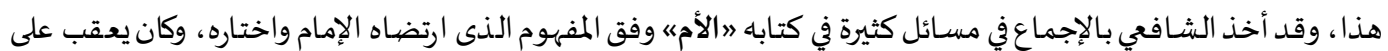

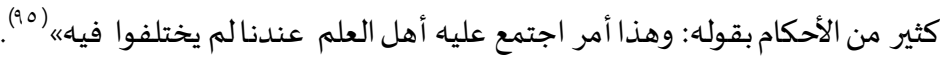
المعلم التاسع: الاعتماد على القياس والتوسُّع فيه.

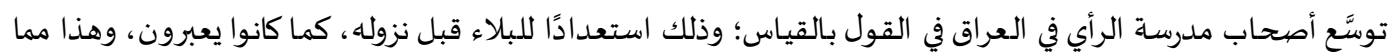
باعد بينهم وبين مدرسة الحديث في الحجاز.

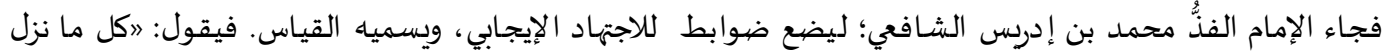

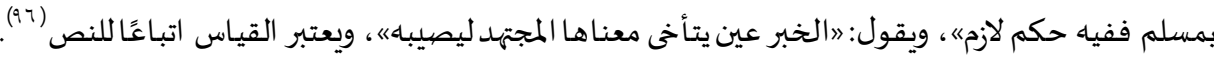

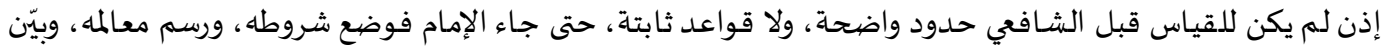

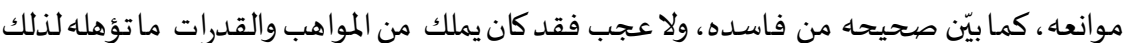

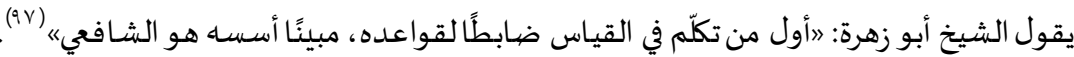

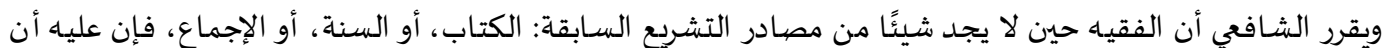

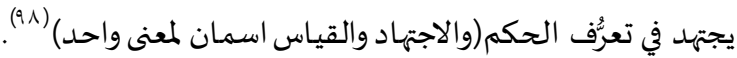

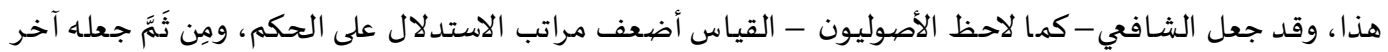

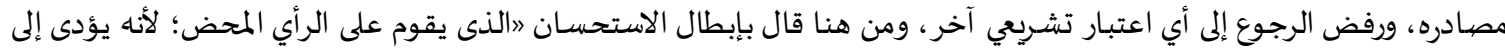

منهجية الإمام محمد بن إدرس في الفقه والأصول: ص عV.

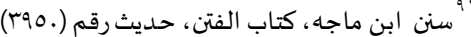

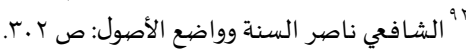

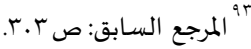

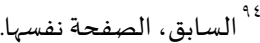

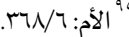

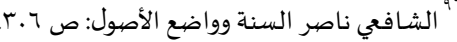

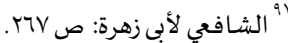
| 
البلبلة في الأحكام والفوضى في التشريع، كما يؤدى إلى تفريق كلمة المسلمين؛ لأن ما يراه البعض حسنًا، قد لا يكون كذلك عند البعض الآخر " (99)

وجملة القول: أن القياس الذى أخذ به الشافعي إنما أخذه استدلالاً بالكتاب والسُّنَّة والآثار ، وهو طربقة من طرق البيان

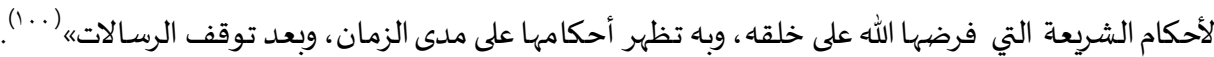
هذا، وسوف نرى في المبحث التطبيقي كيف توسَّع الإمام في المسـائل التي قاسها على غيرها وفقًا لمفهوم القياس عندها.

المعلم العاشر: ضبط الفروع والأحكام بالقواعد الفقهية والأصهولية. من المعالم البارزة والملامح الواضحة، والخصائص المميزة لكتاب "الأمه اعتماده منهج التآخي بين الفقه والأصهول، مع

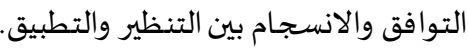
وتجلى هذا التزاوج وظهر هذا الامتزاج في هذا الكم الهائل والكبير من القواعد الفقهية والأصهولية التي اعتمد عليها الإمام ؛ بل وكان جُلها من إنشائه وابتكاره. هذا وتعود فكرة التقعيد الفقهي إلى القرن الرابع الهجري (1 +1)؛ حيث بدأ التأمل في الأحكام والفروع الفقهية في أبواب الفقهه المختلفة؛ حيث يخلص المجتهد من هذا التأمل إلى إدراك المتشابهات بين الأحكام رغم أنها أبواب فقهية متباينة ، كما يدرك أندأن هناك فروقًا لما يبدو مجتمعًا.

ومن خلال هذا التأمل في المسائل يتمكن المجتهد من استنباط الأحكام ووضع القواعد الكلية، وبذلك يخدم الفقه خدمة جليلة؛ لأنها بتلك القواعد يجمع الجزئيات ، ثم يصوغ القاعدة التي تطبق على الأمور التي تستجد فيما بعد.

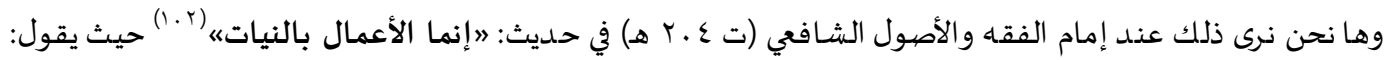

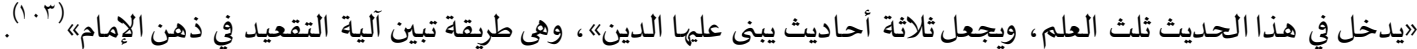
هذا، وقد ذهب بعض الفقهاء إلى أن قواعد الفقه أردع أسـاسية، وتندرج تحتها مجموعة من القواعد الفرعية، وهي: الأولى:

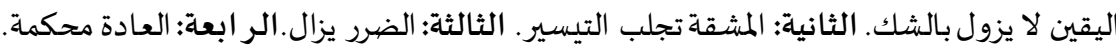
وضهم بعضهم قاعدة خامسة، وهى: 》الأموربمقاصيدهاه، ونظمت هذه القواعد شعرًا بقولهم:

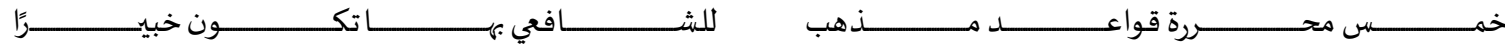

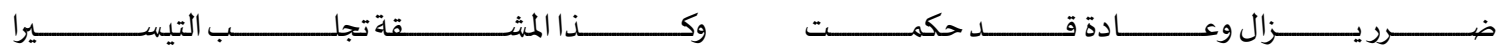

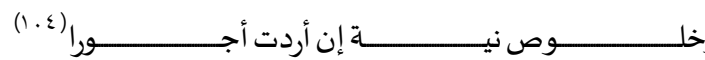

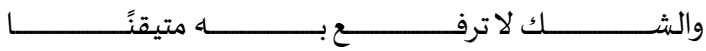

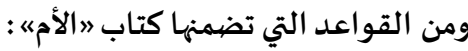
حوى كتاب »الأم《 كثيرًا من القواعد الفقهية والأصيولية منها:

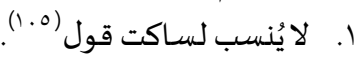

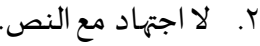
r. الايجوز تأخير البيان عن وقت الحاجة.

"الشافعي في مذهبيه القديم والجديد: ص 0.ع.

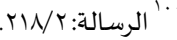

من أوائل ما ظهر من كتب القواعد: 》أصول الكرخي" (ت . عبهـ) على مذهب الحنفية، لعبد الله بن الحسن ابن دلال، الشهير بأبي الحسن الكرخي وكتابه

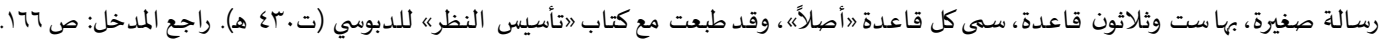

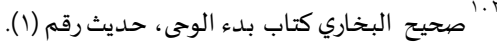
؛ 1. إعانة الطالبين: 1. 1. 1.

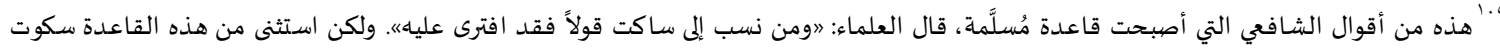

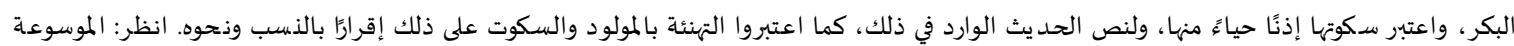

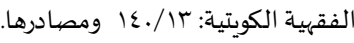
المجلة الدولية للدراسات الإسلامية المتخصصية _ـ المجلدب، العدد ا - 19 ب r 


$$
\begin{aligned}
& \text { ع. اليقين لا يزول بالشك. (7.") }
\end{aligned}
$$

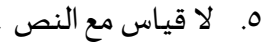

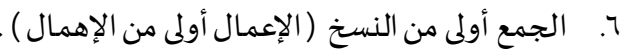

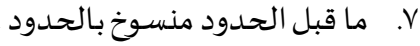

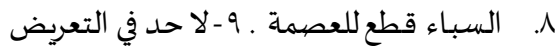

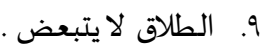

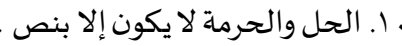

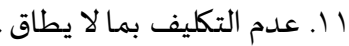

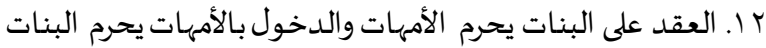

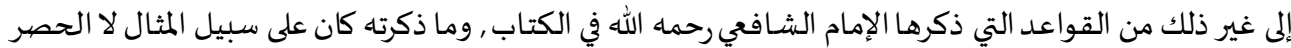

$$
\text { المعلم الحادي عشر: الاستدلال بالمعقول. }
$$

يرى الفقهاء المحققون أن نصوص الكتاب والسنة محصهورة، ومواقع الإجماع معدودة مأثورة، وهى على الجملة متناهية،

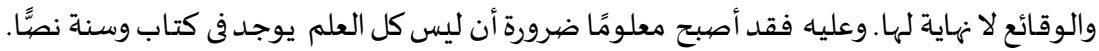

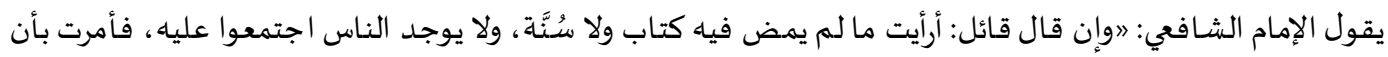

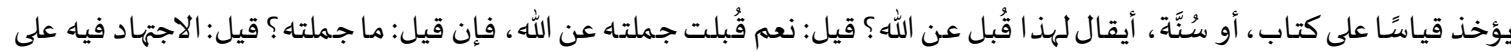

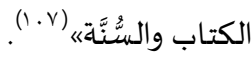
وهذا فإن المنهج عند الشـافعي يقتضى اللجوء إلى المعقول بعامة، والقياس بخاصة عند افتقاد النص من الكتاب والسُّنَّة

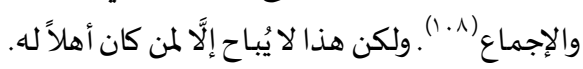

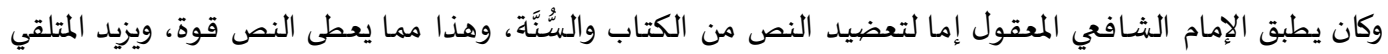
إقناعًا، وكان في كثير من الأحايين يستدل بالمعقول لإقناع المخالفين في مسائل الخلاف ، وهذا وغيره منثور في كتاب " الأم 《 من أوله إلى آخره. المعلم الثاني عشر: مراعاة الإمام للأعراف والبيئات. لا شك أن اعتبار العُرف ورعاية الأحوال والعادات اهتم به الفقهاء جميعهم؛ لكن الناظر لفقه الإمام الشافعي في كتاب

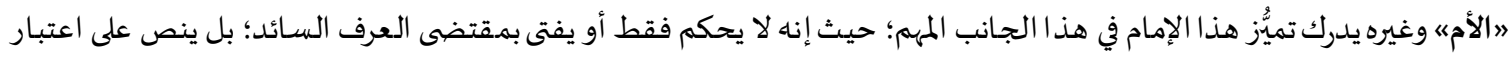
العرف والعادة.

ولاعجب في ذلك فقد تنقل الإمام الشافعي من الحجاز إلى العراق ، ثم إلى مصر ، وأدرك بعد هذا الترحال أن فتاوى المسلمين

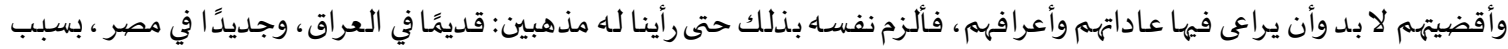
اختلاف البيئات والأعراف. المعلم الثالث عشر: الاهتمام بمقاصيد الشريعة العامة والخاصة بكل باب من أبواب الفقه. المتأمل في كتاب »الأمه يلحظ مدى حرص الإمام الشافعي على رعاية مقاصدد الشربعة العامة من حفظ الدين والعقل

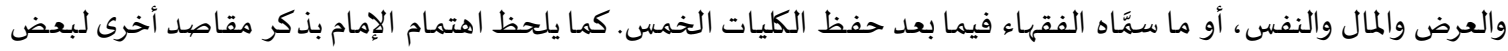
الأبواب الفقهية، كمقصد العفة في النكاح، ومقصيد الستر ونحوهما.

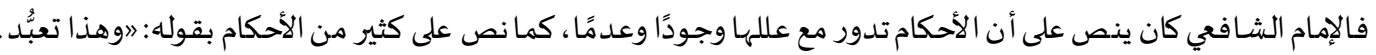

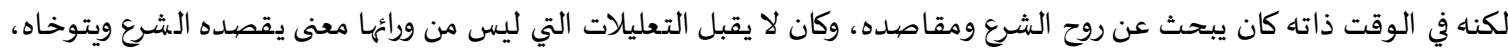

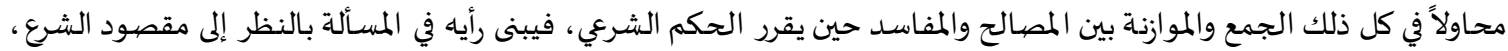
سواء وجد النص أو غاب. 
المعلم الر ابع عشر: اعتماد الإمام الخلاف العالي (الفقه المقارن).

لا شك أن كتاب "الأمه يمثّل فقه الإمام الشافعي واجتهاده الجديد الذي دوّنه أو أملاه على تلاميذه بمصر في آخر حياته.

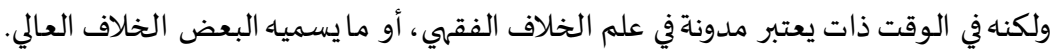

ومَنْ يُراجع كتاب "الأمه" يجدد أنه كان يعرض للخلاف الفقهي بطريقين: الأول: إذا كان الخلاف جزئية فغالبًا ما يذكر

الخلاف مباشرة بعد عرض الموضوع والاستدلال له ، وتوضيح ما توصيَّل إليه اجتهاده فيه، و وفى هذه الصيورة يكون الخلاف محدودةًا.

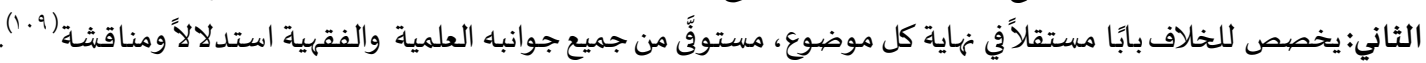

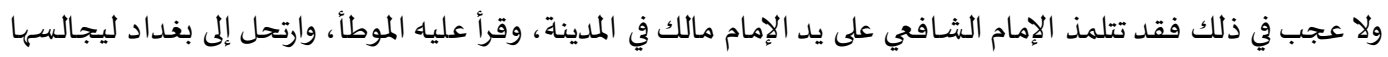

إما مها محمد بن الحسن، فيتعلَّم من أدب هؤلاء: وسلوكهم قبل أن يتعلم من فقههم.

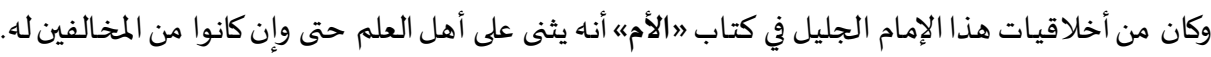

المعلم الخامس عشر: التزاوج بين الفقه والأصهول.

إن الدارس لكتاب "الأمه" وغيره من كُتبب الإمام الشـافعي الفقهية يدرك بوضيوح أن منهجها العلهي قائم على تحليل

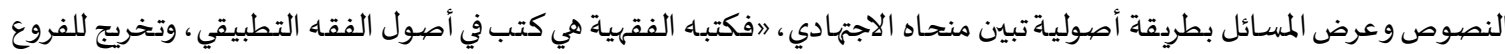
على الأصهول" (11) ، ومنهجهاه في ذلك مميّز جلدًا.

ولا غرو في منهج الشافعي هذا، فالفقها ثمرة من ثمار أصهول الفقه، وفى عهد الإمام كان جُل الأئمة المجتهدين فقهاء

أصوليين أو أصهوليين فقهاء، ولم يرد الفصل بين العلمين إلَّا في عصيور الجمود والركود والنداء بغلق بهاب الاجتهاد.

المعلم السـادس عشر: عدم التوسع في الفقه الافتراضي.

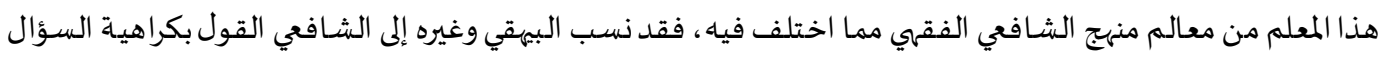

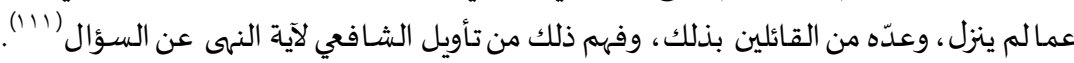

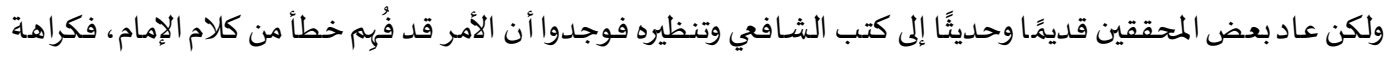

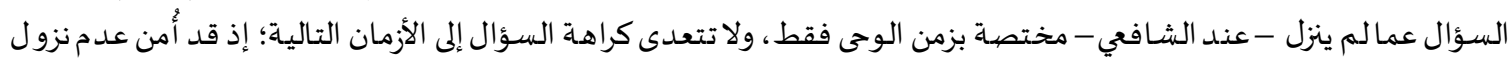

الوحى (1Ir)

أما الجانب التطبيقي فنجد الشـافعي افترض مسـائل، ووضع لها أحكامًا، ولم يقصر اجتهاده فيما وقع ونزل؛ وذلك لأنها

״ارتوى من المعينين الحجازدة والعراقية، وكان يتلقى الأخذ والرد بصدر رحب، فملأ العالم بالمسائل التقديرية وخدم نضيوج

الفقاه《 (1)

هذا ، وقد أرجع بعض المعاصرين لوجود الفقه الافتراضي في كتب الشافعي "لاختيار أقيسته التي كان يضعها والتي عُدَّ بها

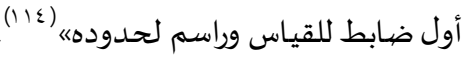

لكن الذى يبدو لي -والله أعلم - أن إقلال الشـافعي أو توسطه في الافتراض مقارنة بغيره من فقهاء الحنفية في العراق مردّه لسببين:

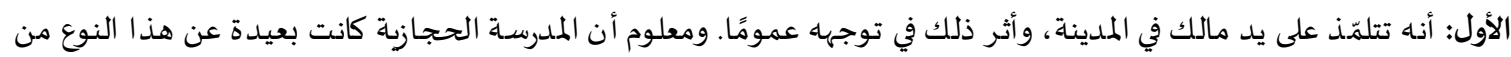

الفقاه.

الثاني: أن الشـافعي كانت لهه عقلية أصيولية ضابطة ونظرته الظاهرية للشريعة في محاولة لتقنين أحكامها الشرعية وتقعيدها بناءً على

أمور يسهل رصدها وتسجيلها، ولا تجنح إلى الافتراض البعيد عن الواقعية.

المعلم السابع عشر: العناية بالنوازل والمستجدات المبات الفقهية.

من الأقوال الثابتة عن الإمام الشافعي قوله: اليست اليست تنزل بأحد من أهل دين الله نازلة إلا وفى كتاب الله الدليل على سبيل

الهدى فهياء (110)

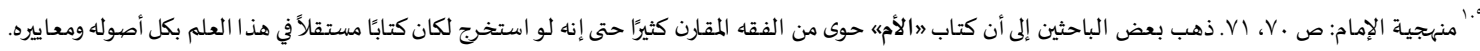

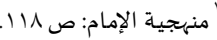

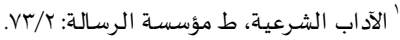

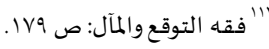

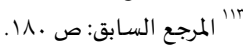

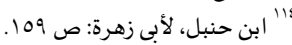

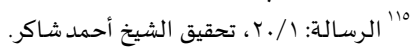

المجلة الدولية للدراسـات الإسلامية المتخصصية _ـ المجلدب، العدد ا - 19 ب r 
فهذا القول من الشافعي يمثل 》إحدى القواعد الكلية المرجوع إليها عند علماء الشربعة وولاة أمور المسلمين، وخاصة عندما تواجههم قضايا وإشكالات لم يسبق عهد بها، وهى قاعدة تفتح الباب للاجتهاد المستمر اللامحدود، فهي تربط بين استمرار الحوادث واستمرار الاجتهاد (17) (1).

وبمراجعة كتاب 》الأمه وجدذا كثيرًا من المستجدات الفقهية والنوازل الطارئة والتي اجتهد فهها الإمام، وببين حكمها بمـا

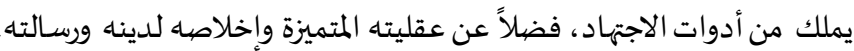
المعلم الثامن عشر: بناء الأحكا موالفتاوى على الجمع والترجيح والاختياروالانفراد الفقهي.

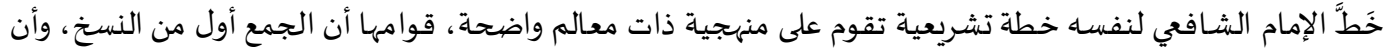

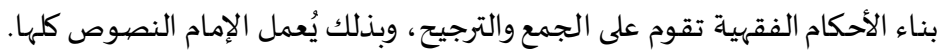

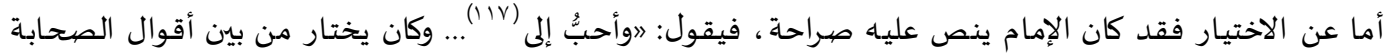
والتابعين (1) ويسوق كل النصيوص في الباب حتى يستدل منها على الحكم الفقهي الذى اختاره ورجّحسه. ورغم رحلة الشافعي القصيرة في هذه الحياة (توفى الإمام عن أربعة وخمسين عامَّا) إلا أنهاه ترك لنا ثروة فقهية وأصولية مبينة على منهجية غير مسبوقة، ويكفى للتدليل على ذلك أن علماء الشافعية من بعده جمعوا له مفرداته الفقهية التي اختارها

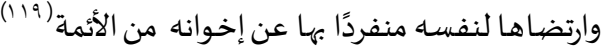

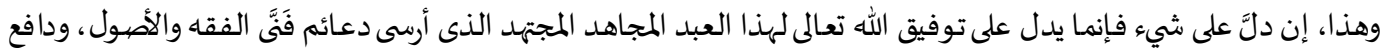
ونافح عنهما منذ نشأته وحتى وفاته، رحماء الله رحمة واسعة .

الخـاتمـة:

وبعد هذه الرحلة الماتعة مع الإمام الشـافي وكتابه 》الأمب خلص البحث إلى مجموعة من النتائج، من أهمها:

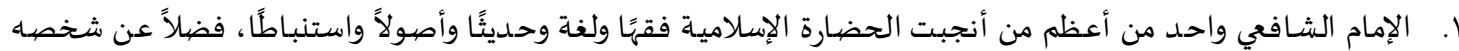

المتفرد، وسلوكه العالي، وأدبه الرفيع، ونصرته لدينها وعروبته.

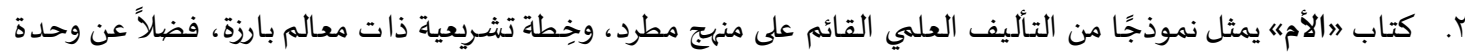

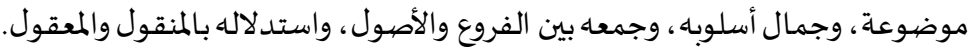

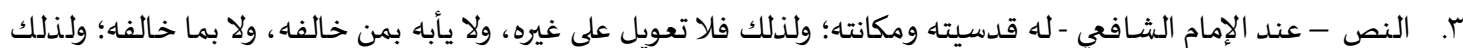

حفظ الناس عن الشـافعي: „إذا صح الحديث فهو مذهبي".

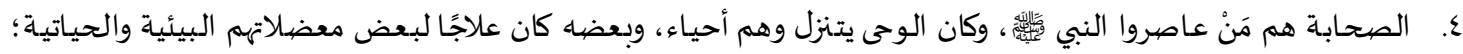

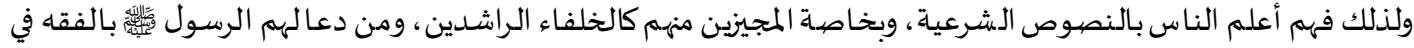

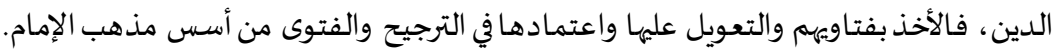

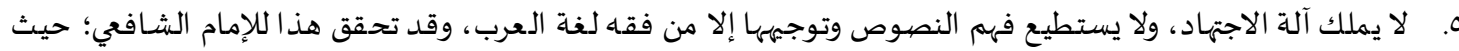

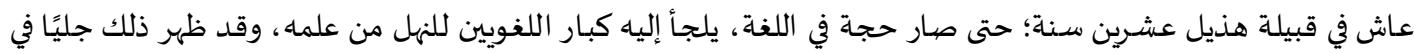
جل فقهاه وفتاويه واختياراته وتوجيهاته. 7. الاعتماد على القياس عند غياب النص والإجماع، وضبط الفروع بالقواعد الفقهية والأصولية، ومراعاة الأعراف والبيئات من

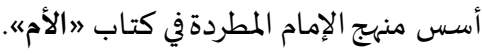
V. التزاوج بين الفقه والأصهول، ومراعاة المقاصدي العامة للشريعة الإسلامية، والمقاصديد الخاصة بكل باب من أبواب الفقهاه ميّز

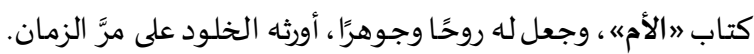

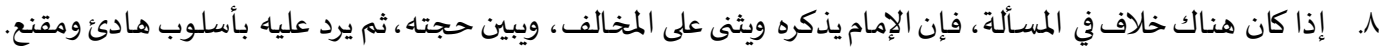

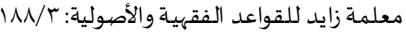
.007/7: الأم:الم 077/7 السابق:

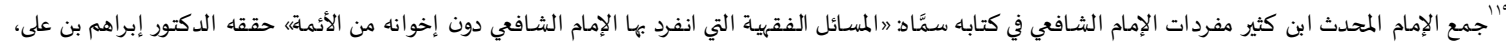
ونشرته مكتبة العلوم والحكم بالمدينة المنورة. المجلة الدولية للدراسـات الإسلامية المتخصصية _ـ المجلد؟ ب، العدد ا - 19 
9. عدم التوسُّح في الفقه الافتراضي إلَّا ما تدعو الحاجة إليه، والعناية بالنوازل والمستجدات الفقهية، وبناء الأحكام والفتوى

على الجمع والترجيح والاختيار ، وأحيانًا الانفراد الفقهي ، كلها سمات لكتاب " الأمه ، تدل على شخصية صاحبه وسعة علمها. • ا. وأخيرًا، الأدب الجام، وحفظ حق العلم وأهله ، ومراعاة حق الأستاذ على تلميذه، وغير ذلك من الشهادات العلمية التي حصل

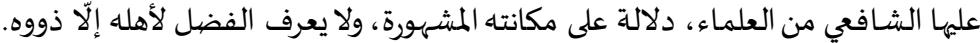
التوصيات:

ا. إعادة تحقيق كتاب " الأم《 للإمام الشافعي وإخراجه على الصهورة التي تليق به؛ حيث إن التحقيقات التي تمت لا تشفى غليل

الباحثين.

r. . جمع القواعد والضوابط الفقهية والأصيولية التي اشتمل عليها كتاب 》الأمه ودراستها دراسة تأصيلية.

r. دراسة مقاصد الشربعة عند الإمام الشافعي نظرًا وتطبيقًا من خلال كتاب 》الأمبه.

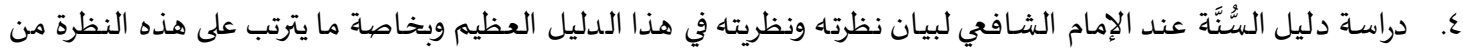

توجياء كثير من الفروع.

0. الأدلة الأصولية المختلف فهيا بين العلماء، وكيف ينظر إلها الإمام ويوجهها من خلال تأصيله في كتاب " الرسالة《، وتطبيقه

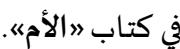

القرآن الكريم.

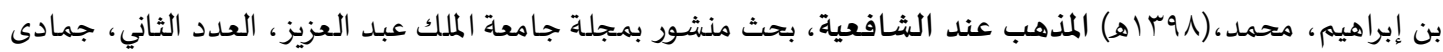

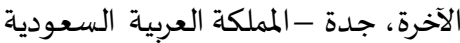

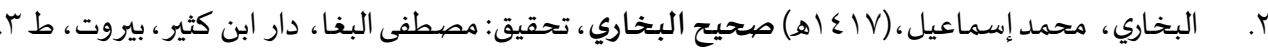

r. الجندي، عبد الحليم،(979 19) الإمام الشـافي ناصر السنة وواضع الأصول، ط: المجلس الأعلى للشئون الإسلامية -القاهرة -

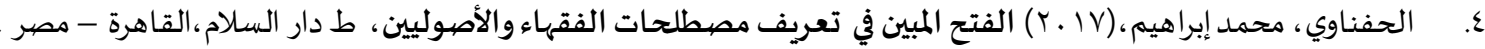

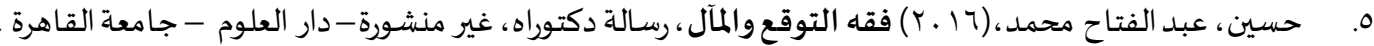

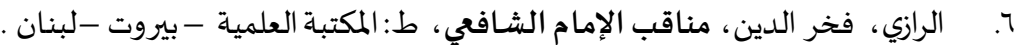

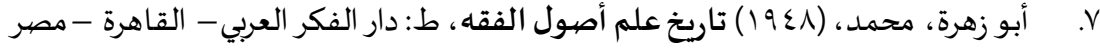

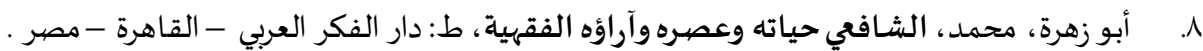

9. ابن السبكي، تاج الدين،(ب99 (19) طبقات الشافعية الكبرى، تحقيق: عبد الفتاح الحلو - محمود الطناحي، ط: دار هجر،

• ا. أبو سليمان، عبد الوهاب إبراهيم،منهجية الإمام محمد بن إدريس الشـافعي في الفقه وأصهوله، ط دار ابن حزم-بيروت -

لبنان .

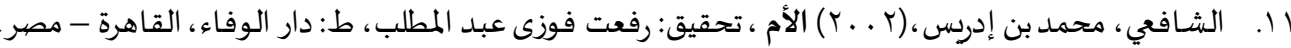

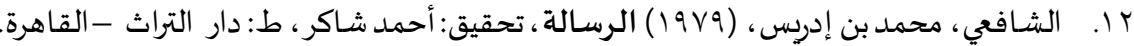

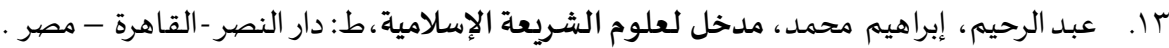

ع ا. العسقلاني، ابن حجر، توالى التأسيس لمعالى ابن إدريس، المطبعة المنيرية - القاهرة - مصر .

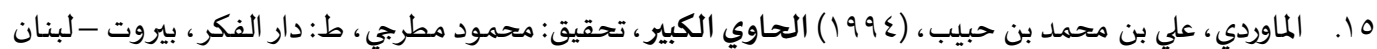

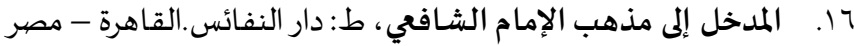

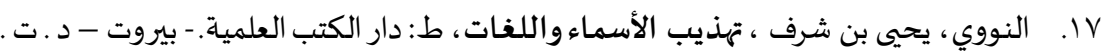

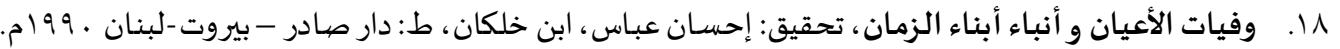




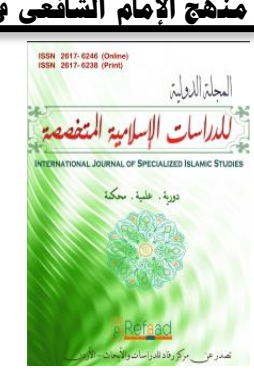

\title{
Approach that Imam Shafi'i - may God have Mercy on him - has Followed in his Book "Al Umm"
}

\author{
Najah Shaher Saad Al Ghadbani \\ Lecturer, Department of Islamic Studies, College of Education, Dawadmi Governorate, \\ Shaqra University, KSA \\ najah@su.edu.sa
}

Received Date: 16/3/2019

Accepted Date: 26/8/2019

Abstract. This research is on the approach that Imam Shafi'i - may God have mercy on him - has followed in his book "Al Umm" which is one of the greatest jurisprudential work of this great scholar; a book that has came out - through his extrapolation - with a set of precise methodological features that indicate the unity of the subject and the method, a fact that clearly outspeaks about the greatness of this book and its author.

This research is presented with an introduction, followed by two research topics and a conclusion, which includes the most important findings and recommendations of this research and then, the research references and index.

In the introduction, I have provided a brief introduction of the book and discussed its importance and have also addressed the reasons for choosing this book for my res earch. I have then provided the research methodology and strategy, and demonstrated the research problem - as is the case in these types of researches.

The first topic is entitled: "Imam Shafi'i and his work "Al-Umm" in which I have dealt with a short biography of Imam Shafi'i, and have then discussed about the importance of "Al-Umm" for the Shafi'i school. This has come up in two sub-sections.

The second to pic is entitl ed: "The general features of the method of Imam Shafi'i in his "Al Umm", in which I have dealt with eighteen features and have also cited for each feature with adequate texts to demonstrate it.

Finally, there is the conclusion which includes the most important research findings and recommendations, and then the most important research references and index is provided.

Key words: Imam Shafi 'i; Shafi'i school; Book "Al Umm".

\section{References:}

- Alqrận Alkrym.

[1] 'bd Ạlrḥym. A̧brạhym Mḥmd, Mdkḥl Llwm Ạlsh̆rych Ạlạslạmyh,Ṭ: Dạr Ạlnṣr- Ạlqạhrh- Mșr

[2] Ạl'sqlạny. Ạbn Ḥjr, Twạly Ạltạ̉sys Lmª̣ly Ạbn A̧Drys, Ạlmṭtbh Ạlmnyryh- Ạlqạhrh- Mṣr

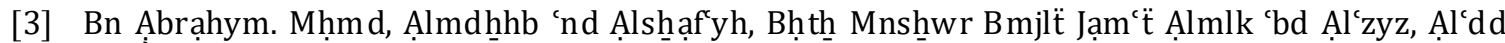
Ạltḥạny, Jmạda Ạlậkhrhh, Jda - Ạlmmlkh Ạl'rbyh Ạls'wdyh, (1398h)

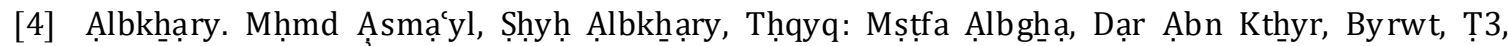
(1417h)

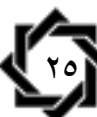


[5] Ạlḥfnạwy. Mḥmd A̧̧brạhym, Alftḥ Ạlmbyn Fy T'ryf Mṣțlhạt Ạlfqhạ’ Wạlạ̉ṣwlyyn, Ṭ Dạr Ạlslạm,Ạlqạhrh - Mșr, (2017)

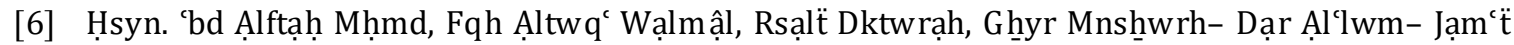
Alqạhrï, (2016)

[7] Ạljndy. 'bd Ạlḥlym, Ạlạmạm Alshhạffy Nạșr Ạlsnh Wwạḍ Ạlạ̉ṣwl, T: Ạlmjls Ạlạ̉ lỵ Llshỷwn Alạslạmyh- Ạlqạhrh - Mșr, (1969)

[8] Ạlmdkḥl A̧la Mdhhhb ẠlạiMạm Ạlshạffy, Ț: Dạr Ạlnfậ̉s.Ạlqạhrh- Mṣr

[9] Ạlmạwrdy. 'ly Bn Mḥmd Bn Ḥbyb, Ạlḥạwy Ạlkbyr, Tḥqyq: Mḥmwd Mțrjy, Ț: Dạr Ạlfkr, Byrwt Lbnạ, (1994)

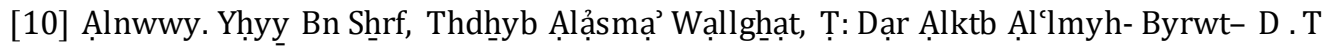

[11] Ạlrạzy. Fkhhr Ạldyn, Mnạqb Ạlạmạm Ạlshạffy, Ț: Ạlmktbh Ạl'lmyh - Byrwt - Lbnạn

[12] Ạbn Ạlsbky. Tạj Ạldyn, Ṭbqạt Ạlshạaf́yh Ạlkbry, Tḥqyq: ‘bd Ạlftạh Ạlḥlw- Mḥmwd Ạlț̣ạhy, Ṭ: Dạr Hjr, Ạlqạhrh- Mṣr, (1992)

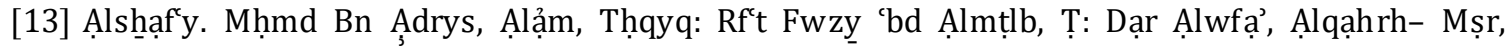
(2002)

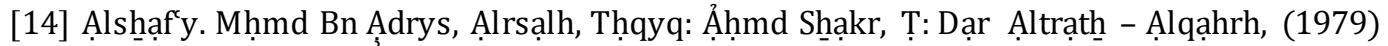

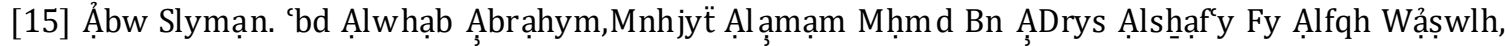
T Dạr Abn Hzm- Byrwt - Lbnạn

[16] Ạ̉bw Zhrh. Mḥmd, Tạrykh 'lm Ạ̉ṣwl Ạlfqh, Ṭ: Dạr Ạlfkr Ạl'rby- Ạlqạhrh - Mṣr, (1948)

[17] Ạ̉bw Zhrh, Mḥmd, Ạlshạf'y Hyạth W'ṣrh Wậrậ̉h Ạlfqhyh, Ṭ: Dạr Ạlfkr Ạl'rby- Ạlqạhrh- Mṣr

[18] Wfyạt Ạlạ̉yạn Wạ̉nbạ Ạ̉bnạ’ Ạlzmạn, Thqyq: Ạ̧sạn 'bạs, Ạbn Khlkạn, T: Dạr Șạdr- ByrwtLbnan, (1990). 